\title{
Aquifer Characterization at the General Motors Harrison Division Plant, Tuscaloosa, Alabama
}

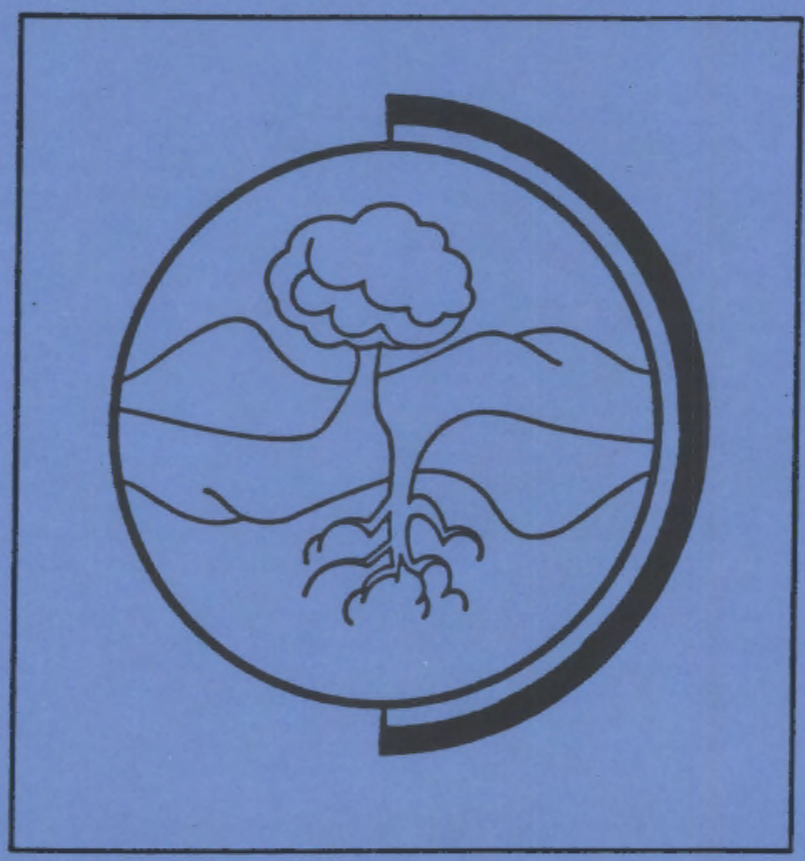

October 1989

Prepared for the U.S. Department of Energy under Contract DE-AC06-76RLO 1830

Pacific Northwest Laboratory Operated for the U.S. Department of Energy by Battelle Memorial Institute 


\title{
DISCLAIMER
}

This program was prepared as an account of work sponsored by an agency of the United States Government. Neither the United States Government nor any agency thereof, nor Battelle Memorial Institute, nor any or their employees, makes any warranty, expressed or implied, or assumes any legal liability or responsibility for the accuracy, completeness, or usefulness of any information, apparatus, product, or process disclosed, or represents that its use would not infringe privately owned rights. Reference herein to any specific commercial product, process, or service by trade name, trademark, manufacturer, or otherwise, does not necessarily constitute or imply its endorsement, recommendation, or favoring by the United States Government of any agency thereof, or Battelle Memorial Institute. The views and opinions of authors expressed herein do not necessarily state or reflect those of the United States Government or any agency thereof.

\author{
PACIFIC NORTHWEST LABORATORY \\ operated by \\ BATTELLE MEMORIAL INSTITUTE \\ for the \\ UNITED STATES DEPARTMENT OF ENERGY \\ under Contract DE-AC06-76RLO 1830
}

Printed in the United States of America

Available to DOE and DOE contractors from the

Office of Scientific and Technical Information, P.O. Box 62, Oak Ridge, TN 37831;

prices available from (615) 576-8401. FTS 626-8401.

Available to the public from the National Technical Information Service,

U.S. Department of Commerce, 5285 Port Royal Rd., Springfieid, VA 22161.

NTIS Price Codes, Microfiche A01

\begin{tabular}{|c|c|}
\hline \multicolumn{2}{|c|}{ Printed Copy } \\
\hline Pages & $\begin{array}{l}\text { Price } \\
\text { Codes }\end{array}$ \\
\hline$\overline{001-025}$ & $\overline{\mathrm{A} 02}$ \\
\hline $026-050$ & $\mathrm{~A} 03$ \\
\hline $051-075$ & $\mathrm{~A} 04$ \\
\hline $076-100$ & $\mathrm{~A} 05$ \\
\hline $101-125$ & A06 \\
\hline $126-150$ & $\mathrm{~A} 07$ \\
\hline $151-175$ & $\mathrm{~A} 08$ \\
\hline $176-200$ & $A 09$ \\
\hline $201-225$ & A10 \\
\hline $226-250$ & A11 \\
\hline $251-275$ & A12 \\
\hline $276-300$ & A13 \\
\hline
\end{tabular}


AQUIFER CHARACTERIZATION AT THE

GENERAL MOTORS HARRISON DIVISION PLANT, TUSCALOOSA, ALABAMA

S. P. Luttrell

W. E. Cronin

S. H. Hall

October 1989

Prepared for the U.S. Department of Energy under Contract DE-AC06-76RL0 1830

Pacific Northwest Laboratory

Richland, Washington 99352 


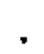




\section{FOREWORD}

Seasonal thermal energy storage (STES) involves storing thermal energy, such as winter chill, summer heat, and industrial waste heat, for future use in heating and/or cooling buildings or for industrial processes. Widespread development and implementation of STES would significantly reduce the need to generate primary energy in the U.S. Recent data indicate that STES is technically suitable for providing $5 \%$ to $10 \%$ of the nation's energy, with major contributions in the commercial and industrial sectors and in district heating and cooling applications.

Aquifer thermal energy storage (ATES) is predicted to be the most costeffective technology for seasonal storage of low-grade thermal energy. Approximately $60 \%$ of the U.S. is underlain by aquifers that are potentially suitable for underground energy storage. Chill ATES has the potential to substantially reduce energy consumption and, especially, summer peak cooling electrical demand. However, the geohydrologic environment that the system will use is a major element in system design and operation, and this environment must be characterized for development of efficient energy recovery.

This report describes aquifer characterization of a site proposed for an ATES chill systen at the General Motors Harrison Division Plant in Tuscaloosa, Alabama. The aquifer characterization work was conducted by the U.S. Department of Energy's Pacific Northwest Laboratory (Seasonal Thermal Energy Storage Program) in cooperation with the University of Alabama as part of efforts to assess the use of chill ATES for industrial cooling. The Pacific Northwest Laboratory is operated by Battelle Memorial Institute for the Department of Energy under contract DE-AC06-76RLO 1830. The project was managed by Dr. C. Everett Brett, Director of the University of Alabama Natural Resources Center.

Land is D. Kannberg, Manager

Seasonal Thermal Energy Storage Program 
. 


\section{SUMMARY}

The General Motors corporation is studying the feasibility of aquifer thermal energy storage (ATES) for cooling purposes at its Harrison Division plant in Tuscaloosa, Alabama. To determine the characteristics of the aquifer underlying the plant, the Pacific Northwest Laboratory (PNL) gathered information about the environment of the aquifer and conducted tests to determine the aquifer's transmissivity and flow. From these tests, calculated estimates of ground-water velocity and flow direction were made.

Nine wells were drilled at the plant site. Apparently, a confining bed of clay locally divides the aquifer into two separate units, one confined and one unconfined. An initial attempt to determine the hydraulic gradient in the aquifer was complicated by the resulting discrepancies in water levels among wells as well as by offsite pumping of the same aquifer; however, an estimate of the direction and magnitude of the hydraulic gradient for the composite aquifer was made. Two other types of tests successfully provided data for ground-water flow velocity for ATES design. A constant-discharge and recovery test was conducted to determine transmissivity (hydraulic conductivity). A single-well tracer test was also conducted, and results of the two tests were used conjunctively to estimate ground-water flow velocity.

Transmissivity was found to be approximately $2000 \mathrm{ft}^{2} /$ day at two wells closest to the pumped well in the parking lot of the General Motors plant. The average hydraulic conductivity is assumed to be approximately $40 \mathrm{ft} / \mathrm{day}$ in the same vicinity. The calculated ground-water velocity is approximately $3.25 \mathrm{ft} /$ day with an effective porosity of approximate $7 y$. $6 \%$. 


\section{CONTENTS}

FOREWORD ..................... $i$ i $\ldots \ldots$

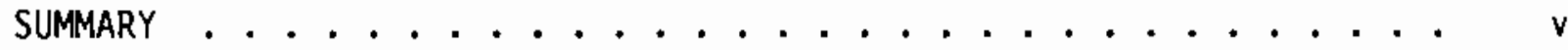

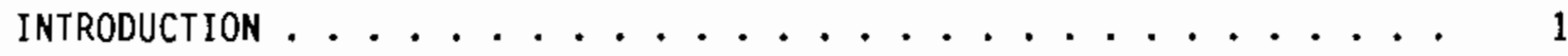

METHODS AND HYDROGEOLOGICAL SETTING .............. 3

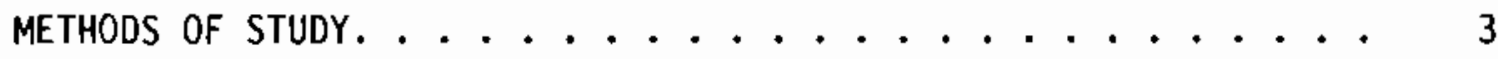

HYDROGEOLOGIC SETTING .................... 5

Stratigraphy .......................... 5

Hydrogeology ........................ 5

TESTS AND RESULTS .......................... 13

CONSTANT-DISCHARGE AND RECOVERY AQUIFER TEST . . . . . . . 13

Well Design. . . . . . . . . . . . . . 13

Test Method. .................. 13

Methods of Analysis............... 14

Data Discussion and Analyses ........... 14

Sumary of Test Analyses ............ . 16

SINGLE-WELL TRACER TEST . . . . . . . . . . . . 17

Test Method. . . . . . . . . . . . 17

Tracer Injection ................... 18

Field Measurements ............ 19

Pumpback of the Tracer . . . . . . . . . . 19

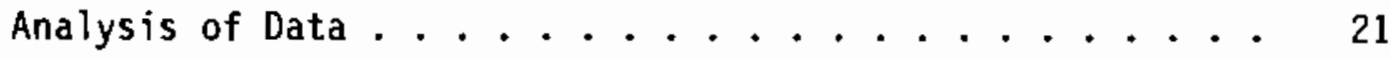

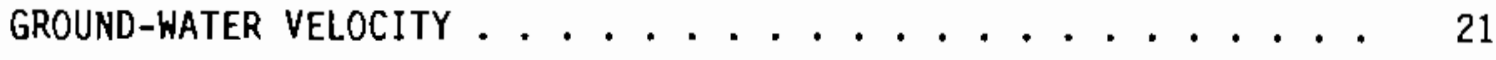

Darcy's Law. ................. 21

Tracer Test. ................. 21

Simultaneous Analysis. .............. 23 


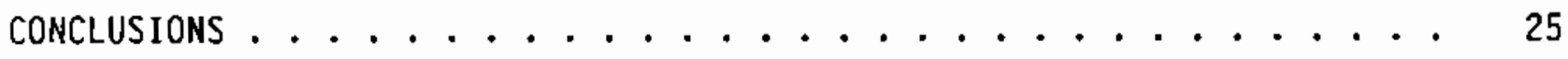

REFERENCES. ........................ 27

APPENDIX A - DRILLERS' LOGS FOR WELLS DRILLED IN THE VICINITY

OF THE GENERAL MOTORS HARRISON DIVISION PLANT . . . . . A.1

APPENDIX B - PLOTS OF AQUIFER TEST DATA FOR A TEST CONDUCTED

AT THE GENERAL MOTORS HARRISON DIVISION PLANT. . . . . . B. B 


\section{FIGURES}

1 Location of the GM Site and Wells Located Near the Site ..... 4

2 Geologic Cross Section Beneath the GM Site ......... 6

3 Ground-Water Level Elevation Map for the GM Site, Measured May 3, 1989 . . . . . . . . . . . 8

4 Hydrographs for Wells 5 and 9 at the GM Site from May 9 to May 18,1989................. 9

5 Hydrographs for Wells 1, 2, 3, 5, 7, and 9 at the GM Site.... 10

6 Concentration of Lithium Bromide Tracer Versus Time for the Pump-Back Portion of the Tracer at the GM Site . . . . . 20

7 Plot of Velocity Versus Effective Porosity by Both the Tracer Test Method and Darcy's Law . . . . . . . . . . . 22

\section{$\underline{\text { TABLES }}$}

1 Casing Elevations, Depth-to-Water Measurements, and Water-Level Elevations for Wells at the GM Site . . . . . . . . . . 7

2 Well Design Information for Wells at the GM Site . . . . . . . 13

3 Summary of Aquifer Test Analyses for the GM Site . . . . . . . 17 



\section{INTRODUCTION}

General Motors (GM) is studying the feasibility of aquifer thermal energy storage (ATES) for cooling purposes at their Tuscaloosa, Alabama, Harrison Division plant. An understanding of aquifer characteristics and geometry, flow direction, and velocity are essential to determine the location and design of ATES production and injection wells. The purpose of this study is to provide estimates of aquifer parameters in order for feasibility studies to be conducted. Previous work at the GM location was conducted in 1984, and in 1988, The Pacific Northwest Laboratory(a) staff, supported by the U.S. Department of Energy, furthered the study. (b)

This report presents aquifer characteristics, flow direction, velocity, and geometry determined by evaluating drilling information and providing the results of two types of tests: a discharge/recovery pumping test and a single-well tracer test. Hydraulic gradients were examined but are not conclusive for the entire flow field.

This report contains two further sections. The first part sets out methodological and environmental backgrounds, including the locations of wells drilled at the GM plant and information obtained by PNL on the stratigraphy, gradients, and water levels. The second section reports on the conduct and results of testing: first, on the discharge/recovery test and, second, on the single-well tracer test. The former test was designed to investigate transmissivity and storage, the latter to estimate flow velocity. Ground-water velocity is calculated using the tracer and pump test results conjunctively.

(a) The Pacific Northwest Laboratory is operated by Battelle Memorial Institute for the U.S. Department of Energy under contract DE-ACO6-76 RLO 1830.

(b) Letter report by J. L. Smoot, Evaluation of the Unconfined Aquifer in the Vicinity of General Motor's Rochester Products Plant, Tuscaloosa, Alabama, February 1989. 



\section{METHODS AND HYDROGEOLOGIC SETTING}

\section{METHODS OF STUDY}

Previous geologic and hydrologic information and data were evaluated in order to establish a conceptual understanding of the aquifer system and to plan for additional tests. Two types of tests were planned: 1) a long-term aquifer pumping test and 2) a tracer injection/pump-back test. In addition, water levels in wells were planned to be measured in order to calculate the hydraulic gradient. Figure 1 shows the GM site and locations of the wells.

A long-term (48 to 72 h) constant-discharge aquifer test was planned. The purpose of the test was to determine the transmissivity, from which hydraulic conductivity can be calculated. The evaluation of the geologic and hydrologic data indicated that a possible confining bed composed of clay material existed within the aquifer. Therefore, an evaluation of hydraulic responses above and below this confining bed during the pumping test was planned. Wells completed above and below the confining bed as well as composite wells were monitored during the test.

A tracer injection/withdrawal test was planned to be conducted following full recovery from the aquifer test. The purpose of the test was to determine ground-water velocity. A lithium bromide solution was mixed with aquifer water and was injected into the pumping well. The residence time of the tracer in the aquifer was based on a velocity calculated from preliminary results of the aquifer test and hydraulic gradient analyses. The tracer was removed 2-1/2 days later by pumping, and the concentration of the tracer was measured over the time of withdrawal.

Water levels were measured for the hydraulic gradient analysis once before the aquifer pumping test was conducted. Yeong $K$. Song from the University of Alabama also measured water levels on several occasions after the test was completed. An evaluation of other nearby pumping centers that may affect hydraulic heads both spatially and over time was conducted. Although an evaluation of hydraulic gradients both above and below the confining bed may have proved useful, the wells were not constructed in a manner that would allow a meaningful evaluation. 


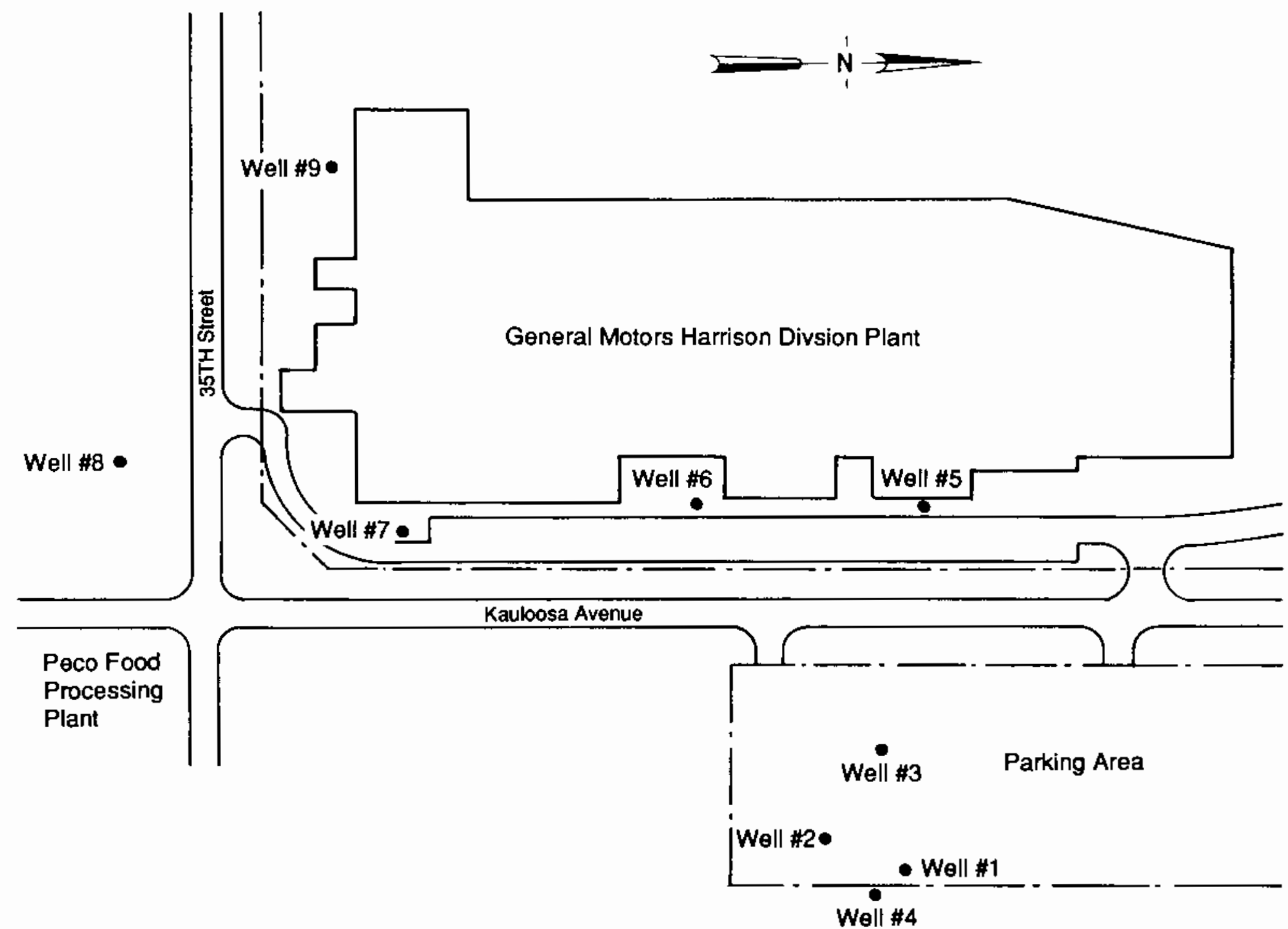

FIGURE 1. Location of the GM Site and Wells Located Near the Site 


\section{HYDROGEOLOGIC SETTING}

This section discusses the general stratigraphy, hydrogeology, and evaluation of other pumping centers near the GM site.

\section{Stratigraphy}

The stratigraphy in the area of the GM plant is composed of unconsolidated sands, gravels, and clays of the undifferentiated Coker formation and/or recent terrace gravels that overlie the Pottsville formation. These unconsolidated materials are approximately $80 \mathrm{ft}$ thick near the GM site. The upper part ( 0 to $15 \mathrm{ft}$ ) consists mainly of clay and sandy clay. A clay layer, varying in thickness, is common near the center of the unconsolidated unit. Coarse sand and gravels are located near the bottom of the unit. The underlying Pottsville formation consists of shales and limestones, with relatively low permeabilities compared to the unconsolidated sediments. The unconsolidated sediments compose the only unit in the vicinity that has potential for ATES use.

Figure 2 is a geologic cross section through the GM site. Appendix A contains several drillers' logs for the vicinity of the GM site.

\section{Hydrogeology}

\section{Hydrostratigraphy}

The undifferentiated sands and gravels overlying the Pottsville formation make up the major aquifer in the vicinity of the GM site. The saturated thickness of the aquifer is approximately $70 \mathrm{ft}$. The depth to water in the vicinity of the GM site is about 18 to $20 \mathrm{ft}$. Results of this study indicate that the clay layer may be acting as a confining or semiconfining layer in the area of the GM plant. It is assumed that two separate hydrostratigraphic units exist: one unconfined and one confined.

\section{Hydraulic Gradient Analyses}

Water-level measurements were made in several wells on several different occasions to determine the direction and magnitude of the hydraulic gradient. Table 1 lists the data from these measurements. 


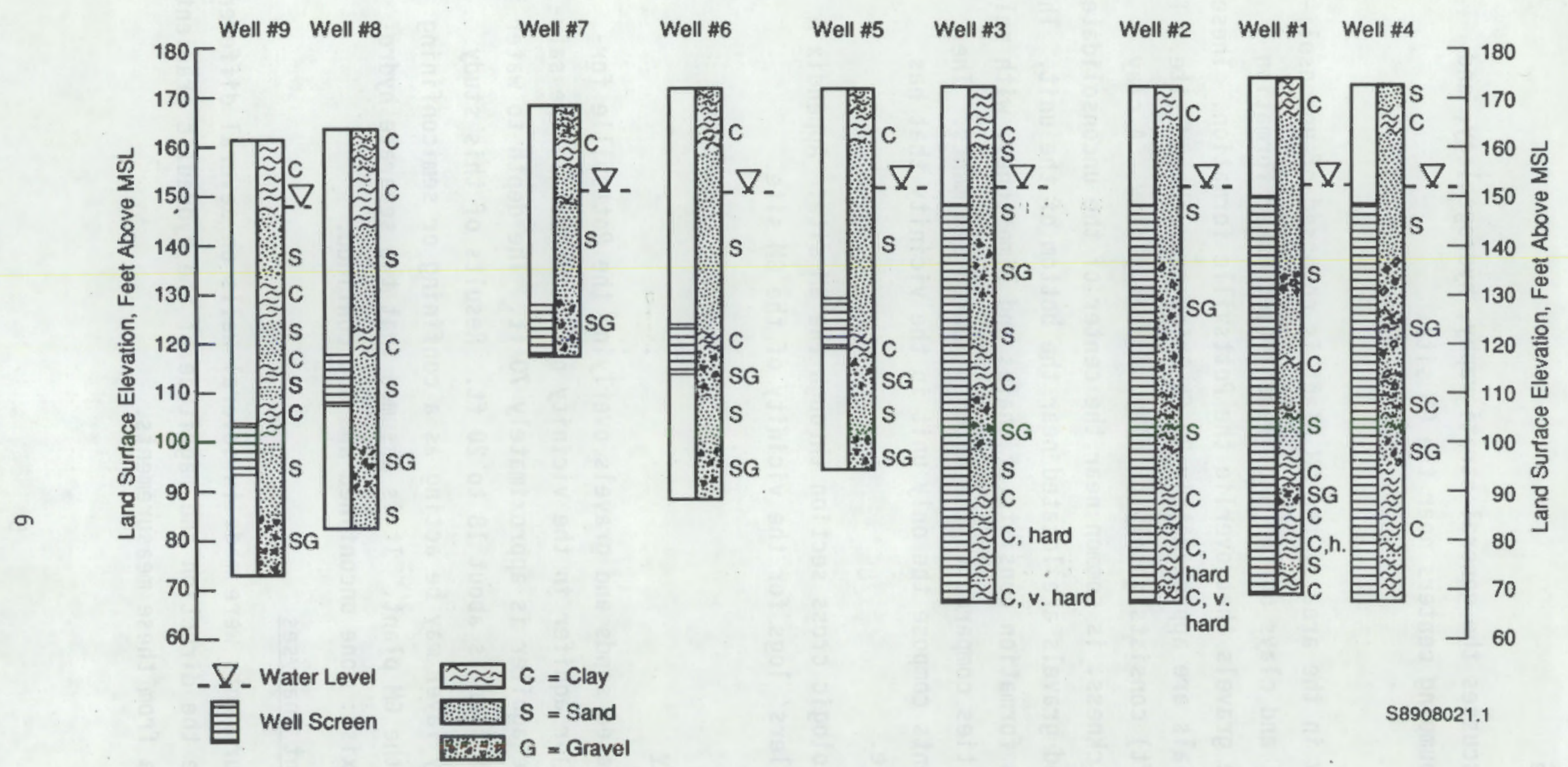

FIGURE 2. Geologic Cross Section Beneath the GM Site 
TABLE 1. Casing Elevations, Depth-to-Water Measurements, and Water-Level Elevations for Wells at the GM Site

We11

Casing

Date and Time

Number Elevation, $\mathrm{ft}$ of Measurement

1

173.25

$5 / 03 / 89$

$9: 42$

$5 / 10 / 89$

$12: 02$

$5 / 11 / 89$

$16: 38$

$5 / 13 / 89$

$11: 32$

$5 / 18 / 89$

$9: 20$

2

171.98

$5 / 03 / 89$

$5 / 10 / 89$

$5 / 11 / 89$

$5 / 13 / 89$

$5 / 18 / 89$

$9: 53$

12:02

$16: 38$

$11: 32$

$9: 20$

$5 / 03 / 89$

$5 / 10 / 89$

$5 / 11 / 89$

$5 / 13 / 89$

$5 / 18 / 89$

11:01

$12: 02$

$16: 38$

$11: 32$

9:20

$5 / 03 / 89$

9:51

$5 / 03 / 89$

$5 / 10 / 89$

$5 / 11 / 89$

$5 / 13 / 89$

$5 / 18 / 89$

$11: 10$

$12: 02$

$16: 38$

$11: 32$

9:20

$5 / 10 / 89$

$5 / 11 / 89$

$5 / 13 / 89$

$5 / 18 / 89$

12:02

$16: 38$

$11: 32$

$9: 20$

5/03/89 11:27

$5 / 10 / 89$

$5 / 11 / 89$

12:02

$5 / 13 / 89$

$16: 38$

$5 / 18 / 89$

$11: 32$

9:20

$5 / 03 / 89$

$5 / 10 / 89$

$5 / 11 / 89$

$5 / 13 / 89$

$5 / 18 / 89$

$11: 32$

12:02

$16: 38$

$11: 32$

9:20

160.85

\begin{abstract}
$5 / 18 / 89$
\end{abstract}
Depth-to-
Water ft

20.63

21.14

21.35

20.98

20.78

19.85

20.28

20.45

20.11

19.96

20.21

20.59

20.69

20.40

20.28

21.71

19.72

19.95

19.93

19.88

19.75

20.48

20.43

20.31

20.28

18.59

18.79

18.78

18.58

18.63

12.49

12.78

12.68

12.22

12.84
Water-Leve1

Elevation, $\mathrm{ft}$

152.62

152.11

151.90

152.27

152.47

152.13

151.70

151.53

151.87

152.02

151.76

151.38

151.28

151.57

151.69

152.61

151.30

151.07

151.09

151.14

151.27

150.42

150.47

150.59

150.62

150.32

150.12

150.13

150.33

150.28

148.36

148.07

148.17

148.63

148.01 
Ground-water flow direction in the vicinity of the GM plant is generally towards the southwest. Computer gradient analysis done by Yeong K. Song of the University of Alabama indicates that the gradient is approximately 0.005 , using wells 5, 7, and 9 in the calculations. With wells 3, 5, and 7, a gradient of approximately 0.0029 was calculated. Preliminary analys is of the gradient near wells $1,2,3$, and 4 indicate a gradient of approximately 0.005 . A map of the water-level elevation as measured in wells $1,2,3,4$, 5 , and 7 is shown in Figure 3.

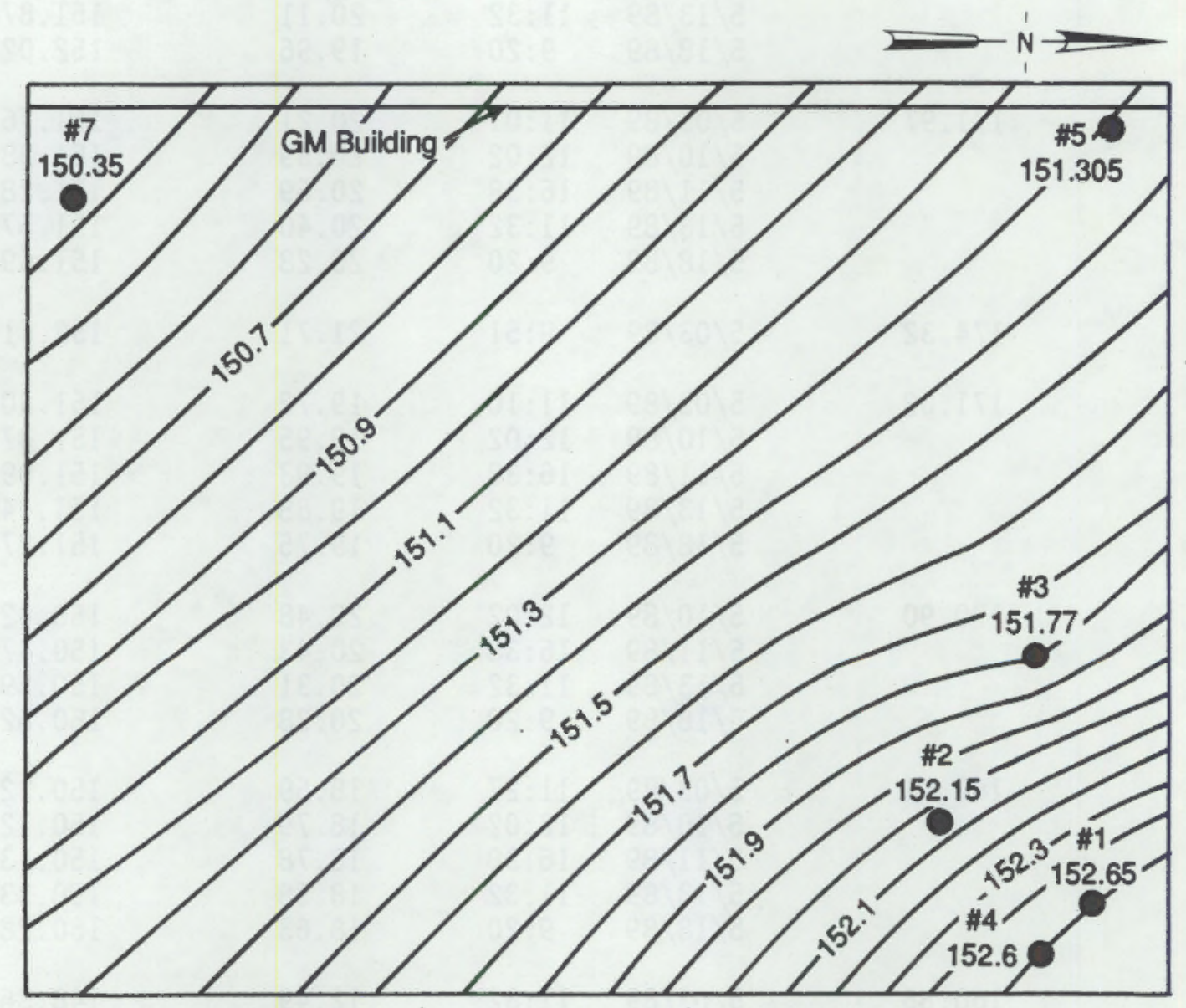

FIGURE 3. Ground-Water Level Elevation Map for the GM Site, Measured May 3, 1989 
Wells are completed in two different hydrostratigraphic units, and some are composite wells completed in both units (well design is discussed in a later section). In addition, ground-water pumping from a nearby processing plant (discussed later) may influence water levels. There are two resulting limitations in the gradient analyses:

- Responses in wells completed in the two hydrostratigraphic units are not similar in magnitude. Figure 4 indicates hydrographs for wells 5 (completed above the confining bed) and 9 (completed below the confining bed) for several days. It is obvious that well 9 has a much greater magnitude response than well 5 to a nearby cause, suspected to be from off-site pumping.

- Water-level elevations in the two hydrostratigraphic units may not be equal. Figure 5 indicates that the water-level elevation in well 9 is much lower than the water-level elevations of the other wells, which are more closely grouped.

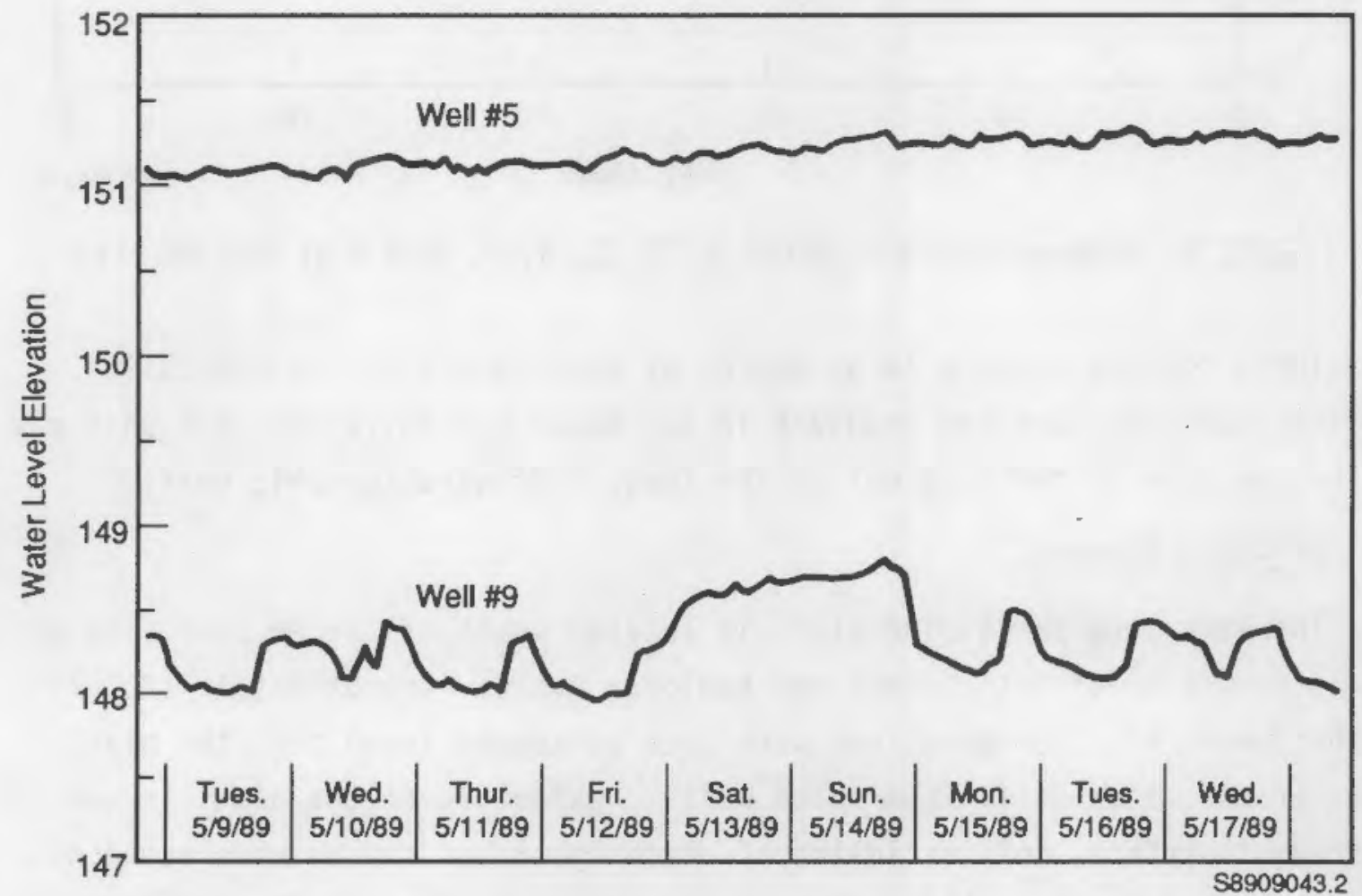

FIGURE 4. Hydrographs for Wel1s 5 and 9 at the GM Site from May 9 to May 18,1989 


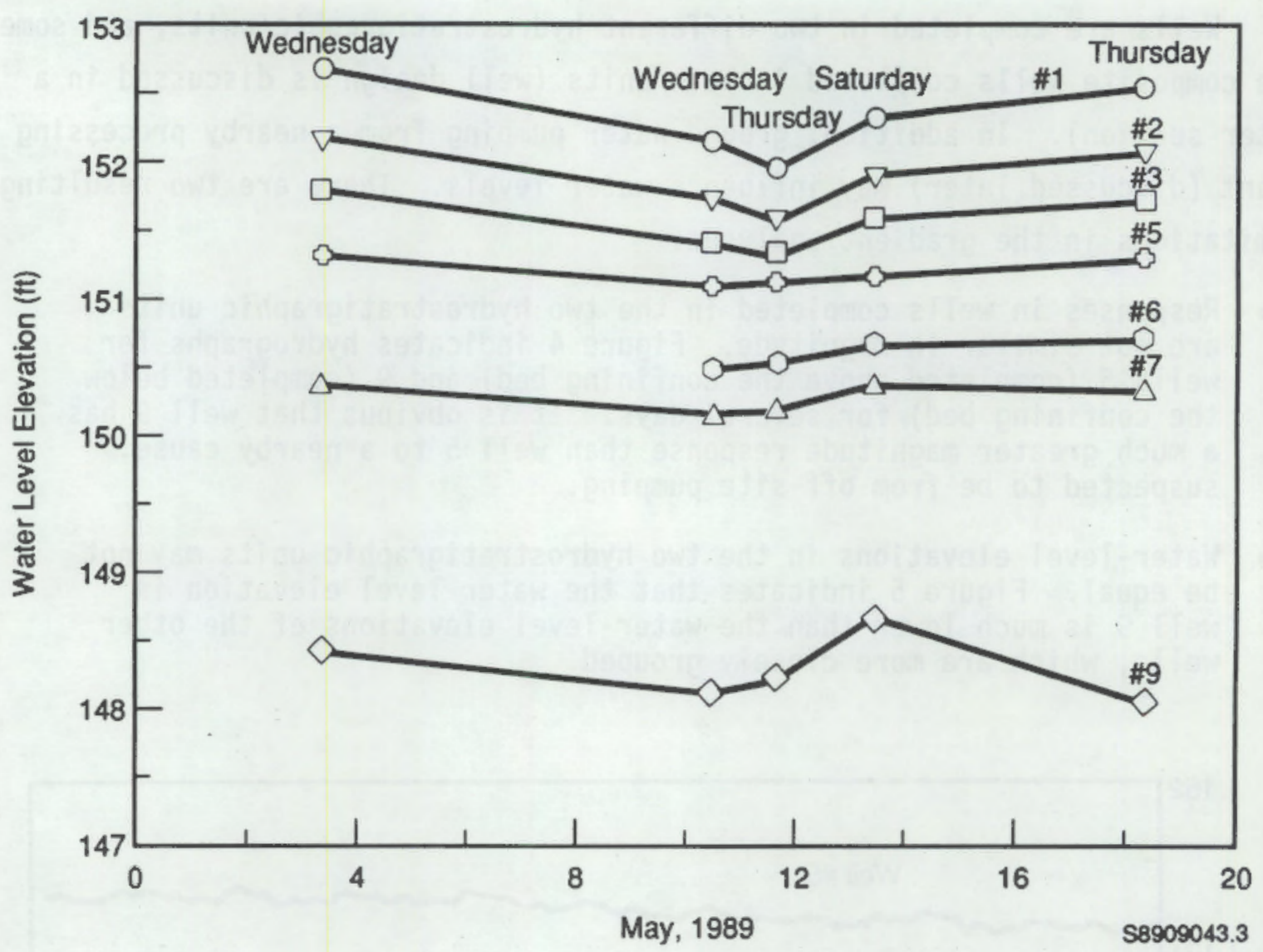

FIGURE 5. Hydrographs for Wells $1,2,3,5,7$, and 9 at the GM Site

These factors cause a large degree of uncertainty in the hydraulic gradient analyses, and the gradient in the upper hydrostratigraphic unit may not be the same as the gradient in the lower hydrostratigraphic unit.

\section{Off-Site Pumping}

The Peco food processing plant is located south of the GM test site at the intersection of 35 th Street and Kauloosa Avenue (approximately $1000 \mathrm{ft}$ south of well 4). Conversations with Peco personnel found that the plant pumps ground water daily from three wells. Water use at the plant is not metered; therefore, only estimates of discharge rates can be made based on the pump sizes in the wells. The pump sizes in the three wells are 10, 15, and $20 \mathrm{hp}$. The pumps operate on a pressure-demand system. The maximum rate of discharge during peak water-use periods is assumed to be from approximately 750 to $1000 \mathrm{gpm}$. Peco personnel indicated the pumping rate on 
weekends is about half the weekday amount. The hydrograph for well 9 (Figure 4) indicates that the water level increases on the weekends and decreases during the week in response to pumping. In addition, the hydrograph shows a daily pattern of water-level fluctuations responding to increased pumping, beginning at night through about mid-day.

Ground-water pumping at the Peco plant may be a major factor affecting the flow direction and gradient at the GM site. It is uncertain to what degree the estimates of flow direction and gradient are representative of the natural flow system. 



\section{IESTS AND RESULTS}

\section{CONSTANT-DISCHARGE AND RECOVERY AQUIFER TEST}

The purpose of this aquifer test was to obtain a better understanding of the transmissivity and, if possible, the storage coefficient of the aquifer in the vicinity of the GM plant. The results of the 1988 aquifer test are in question because of equipment and measurement problems. This aquifer test was conducted to provide more reliable results for ATES design.

\section{Well Design}

Wells 1 through 4 were drilled for aquifer testing at the site in 1984 . Wells 5 through 9 were added in 1988 for further aquifer analysis. Table 2 summarizes the construction of the wells.

\section{Test Method}

A constant-discharge pumping test was conducted from May 4, 1989, at $1015 \mathrm{~h}$, unti1 May 6,1989 , at $1245 \mathrm{~h}$ when the pump was shut off. The total duration was $50 \mathrm{~h}, 30 \mathrm{~min}(3030 \mathrm{~min})$. The ultimate duration of the test was decided by a field analysis of the data. Well 4 was the pumping well, and it was pumped at a constant discharge rate of approximately 260 gallons per minute $(\mathrm{gpm})$. The discharge rate was measured during the test by a pitot

TABLE 2. Well Design Information for Wells at the GM Site

\begin{tabular}{|c|c|c|c|c|c|}
\hline $\begin{array}{c}\text { We11 } \\
\text { Number }\end{array}$ & $\begin{array}{l}\text { Radius, } \\
\mathrm{ft}(\mathrm{a})\end{array}$ & Diameter, in. & $\begin{array}{c}\text { Casing } \\
\text { Material }\end{array}$ & $\begin{array}{c}\text { Screen } \\
\text { Interval, } \mathrm{ft}\end{array}$ & Depth, ft \\
\hline 1 & 39.65 & 2 & PVC & $24-104$ & 105 \\
\hline 2 & 79.9 & 2 & PVC & $24-104$ & 105 \\
\hline 3 & 160 & 2 & PVC & $24-104$ & 105 \\
\hline 4 & NA & 10 & Steel & $24-104$ & 105 \\
\hline 5 & 415.87 & 2 & PVC & $43-53$ & 78 \\
\hline 6 & 461.33 & 2 & PVC & $48-58$ & 83 \\
\hline 7 & 616.76 & 2 & PVC & $41-51$ & 51 \\
\hline 8 & 891.73 & 2 & PVC & $47-57$ & 82 \\
\hline g & 965.38 & 2 & PVC & $58-68$ & 88 \\
\hline
\end{tabular}

(a) The radius refers to the distance of the observation well from the pumping well. This is not applicable (NA) to well 4, the pumping well. 
tube that was located in the discharge line. This method of measurement indicated a rate of approximately 230 to $240 \mathrm{gpm}$. Discharge was also measured by timing the discharge into a 60 -gallon barrel near the beginning of the test and near the end of the test. This volumetric measurement of discharge resulted in a rate of approximately $260 \mathrm{gpm}$; this value was considered the most accurate. The water was discharged across the parking lot into a nearby storm sewer.

Drawdown and recovery data were collected and recorded in wells 1, 2, and 5, and pumping we11 4 using 50-psi transducers and data loggers. Water levels in wells 3,7 , and 9 were measured periodically throughout the test, using steel tapes.

\section{Methods of Analysis}

The data exhibited responses that appeared to follow delayed yield (Boulton 1963) or leaky confined (Cooper 1963) aquifer model responses. Type curves for these are given in Lohman (1972). Use of either set of type curves results in similar values for transmissivity, which is the primary aquifer property of concern for the purpose of this test.

Logarithmic plots of drawdown versus time were matched to type curves for delayed yield. This method was used to obtain estimates of transmissivity and storage.

Analyses of recovery data by the Cooper-Jacob method (Cooper and Jacob 1946) were used on wells 1, 2, 3, and 4 to estimate transmissivity. These values were relied upon primarily for corroborative information.

\section{Data Discussion and Analyses}

The data obtained were generally of high quality and were able to provide quantitative analyses of transmissivity. However, data from wells 5, 7 , and 9 appeared to be influenced by factors other than just pumping in well 4 . A further limitation to the analysis is that it appears that a confining bed of clay locally divides the aquifer into two separate aquifer units, one confined and one unconfined. Wells 1, 2, 3, and 4 are completed across both of these units; wells 5 and 7 are completed above the clay in the unconfined unit; and well 9 is completed below the clay in the confined unit. 


\section{He11 1}

During the first 2 minutes of the pump test, aquifer response showed $4 \mathrm{ft}$ of drawdown. A maximum of approximately $9 \mathrm{ft}$ of drawdown was reached near the end of the discharge test. The data appeared to exhibit a delayed yield or leaky confined response. Abrupt changes in water levels at times of approximately $600,1200,2000$, and 2600 minutes were attributable to possible data-logger malfunction. Plots of the drawdown and recovery data are presented in Appendix B.

Theis curve matching resulted in a value of $2100 \mathrm{ft}^{2} /$ day for transmissivity and $4.8 \times 10^{-4}$ for storage. Analysis of the recovery data provided a value of $2500 \mathrm{ft}^{2} /$ day for transmissivity.

\section{Well 2}

We11 2 had $4.5 \mathrm{ft}$ of drawdown during the first 10 minutes of the test. A maximum drawdown of approximately $7 \mathrm{ft}$ was reached at the end of the test. Immediate changes in water levels at times of approximately 600, 1200, 2000, and 2600 minutes were attributable to possible data-logger malfunction. Plots of the drawdown and recovery data are presented in Appendix $B$.

Theis curve matching resulted in a value of $2000 \mathrm{ft}^{2} /$ day for transmissivity and $8.7 \times 10^{-4}$ for storage. Analysis of the recovery data provided a value of $3000 \mathrm{ft}^{2} /$ day for transmissivity.

\section{Well 3}

Maximum drawdown in well 3 reached approximately $3.2 \mathrm{ft}$ at the end of the pump test. Plots of the drawdown and recovery data are presented in Appendix B.

Because of lack of early data points, well 3 gave several possible match points on the type curve. Transmissivity values corresponding to the different match points ranged from approximately 2,800 to $10,000 \mathrm{ft}^{2} /$ day. Storage values range from $2 \times 10^{-4}$ to $7 \times 10^{-4}$. Analysis of the recovery data for well 3 provided a transmissivity value of $8000 \mathrm{ft}^{2} /$ day. 


\section{Wel1 4}

Well entrance loss was indicated by drawdown of approximately $10.7 \mathrm{ft}$ within the first minute of pumping. Maximum drawdown of about $29 \mathrm{ft}$ was reached at the end of the test. Plots of the drawdown and recovery data are presented in Appendix B.

Type curve matching resulted in a value of $800 \mathrm{ft}^{2} /$ day for transmissivity. Recovery analysis provided a value of $670 \mathrm{ft}^{2} /$ day. These lower values relative to the values obtained from wells 1,2 , and 3 were likely because of the well losses in the pumping well.

\section{Wells 5 and 7}

The logarithmic plots of wells 5 and 7 resulted in data sets that are difficult to match to a type curve. Maximum drawdown values in wells $\mathbf{5}$ and 7 were approximately 0.75 and $0.44 \mathrm{ft}$, respectively. Plots of the drawdown and recovery data are presented in Appendix $B$.

The water-level data in these two wells were apparently affected by other influences not related to pumping in well 4 , as is shown by the large, otherwise unexplainable, deviations from the type curves.

The analyses of early-time data indicated that the transmissivity at well 5 ranges from approximately $4000 \mathrm{ft}^{2} /$ day to as high as $20,000 \mathrm{ft}^{2} / \mathrm{day}$.

Analysis from well 7 is not presented.

\section{Wel1 9}

We11 9 showed fluctuations of water levels during the pump test that did not correspond to pumping. Explanations of these fluctuations are discussed later in this report. Data from this well were not used for calculations of transmissivity.

\section{Summary of Test Analyses}

Table 3 contains a summary of the aquifer test analyses. 
TABLE 3. Summary of Aquifer Test Analyses for the GM Site

\begin{tabular}{|c|c|c|c|}
\hline $\begin{array}{c}\text { Well } \\
\text { Number }\end{array}$ & $\begin{array}{l}\text { Transmissivity (Curve } \\
\text { Matching), } \mathrm{ft}^{2} / \text { day }\end{array}$ & $\begin{array}{l}\text { Storage (Curve } \\
\text { Matching) } \\
\end{array}$ & $\begin{array}{l}\text { Transmissivity } \\
\text { (Recovery), } \mathrm{ft}^{2} / \text { day }\end{array}$ \\
\hline $\begin{array}{l}1 \\
2 \\
3 \\
4 \\
5\end{array}$ & $\begin{array}{c}2,100 \\
2,000 \\
2,800 \\
800 \\
4,000 \text { to } 20,000\end{array}$ & $\begin{array}{c}4.8 \times 10^{-4} \\
8.7 \times 10^{-4} \\
3 \times 10^{-4} \\
---\end{array}$ & $\begin{array}{r}2,500 \\
3,000 \\
8,000 \\
670 \\
-. .\end{array}$ \\
\hline
\end{tabular}

\section{SINGLE-WELL TRACER TEST}

The purpose of the test was to estimate regional advective groundwater flow in order to provide design data for an ATES project.

\section{Test Method}

The tracer test was performed in the single-well drift-and-pumpback mode described by Leap and Kaplan (1988). Using this method, a tracer slug is injected into a test well, is allowed to drift for a period of time, and is retrieved by pumping. The velocity of ground-water flow is calculated as a function of the amount of time required to recover the tracer slug at a given pumping rate. Data analysis also requires an estimate of effective porosity.

The method of Leap and Kaplan was derived for confined aquifers, that is, no dewatering is accounted for in their formula. However, the test at the GM plant was conducted using a pumpback rate of only $60 \mathrm{gpm}$, with a maximum estimated drawdown in pump well 4 of about $5 \mathrm{ft}$, or about $10 \%$ of the aquifer thickness. The effect of this drawdown may be viewed as a small perturbation of effective porosity in the vicinity of the well bore during pumpback.

Leap and Kaplan describe a "velocity shadow" downgradient from the test well, the effect of which is an apparent reduction of flow velocity near the well. As drift time increases, the effect of the shadow decreases. The effect of the shadow is consistent with the fact that within the well bore the porosity is $100 \%$, and horizontal flow rate through the well will be smaller than through the sediments. Thus, the tracer slug will require extra time to be flushed from the well, but that additional time increment will become negligible as drift time increases. Leap and Kaplan offer no method 
to compensate for the effect of a velocity shadow except to perform a series of tests using progressively longer drift times.

The test at the GM plant was designed to minimize the effect of the velocity shadow. The procedure required that immediately after injection of the tracer slug, the tracer solution remaining in the well bore would be displaced to the sediments by injecting into the well an amount of unlabelled water equal to the standing bore volume. This would result in a donut-shaped tracer slug centered about the bore axis. Only the fraction of the tracer immediately upgradient from the well bore would pass through the well and be subject to the effect of the velocity shadow. Unfortunately, design data for the test well indicated a 6 -in.-diameter casing instead of the actual 10-in.-diameter. Therefore, the ground water reserved for the chaser was less than the full standing bore volume.

The results of the tracer test are subject to the same constraints of the aquifer test, namely, that two separate hydrostratigraphic units separated by a confining bed comprise the aquifer.

\section{Tracer Injection}

Ground water collected during previously conducted pumping tests was stored in five 55-gal drums and was available for the tracer test at the test site. On May 8, approximately $50 \mathrm{~g}$ of lithium bromide ( $\mathrm{LiBr}$ ) was added to each of three of the drums to prepare tracer solution. The solution in each drum was mixed by air injection. Untreated ground water and each of the treated drums was sampled for analysis.

Beginning at $1715 \mathrm{~h}$ on May 8 , the tracer solution was injected into pump well 4 at the net rate of $4.0 \mathrm{gpm}$, followed immediately by the untreated water from the two remaining drums. Injection of both tracer and chaser was completed by $1822 \mathrm{~h}$. Transfer of the solutions was accomplished using a 12-v battery-operated marine bilge pump (Mayfair Pro-Line 600 Model 2260 ) connected to a 3/4-in. (I0) garden hose. Maximum flow rate using $50 \mathrm{ft}$ of hose was $4.7 \mathrm{gpm}$.

Volume of the injected solutions was determined by measuring the drums and subtracting 2 in. from the drum height to allow for 1 in. of solution 
remaining at the bottom of each drum (because the pump could not pick up less than about 1-in. depth) and for 1 in. at the top of each drum (because of incomplete filling). Calculations showed that 53.2 gal from each drum was injected into the well.

\section{Field Measurements}

A bromide-ion-selective electrode was available for monitoring the ground water during the pumpback phase of the test. The Corning bromide electrode (model no. 476128) was used in conjunction with an Orion double junction reference electrode (model no. 900200) and a portable Hach ${ }^{(}(\mathrm{a})$ One pH Meter (model no. 43800-00). Outer filling solution for the reference electrode was $10 \% \mathrm{KNO}_{3}$. The Hach meter was used in the millivolt mode, and it was necessary to splice both electrodes to a single BNC connector.

No ionic strength adjuster was used for bromide measurements, and the electrode was calibrated by spiking samples of the ground water with a $1000 \mathrm{mg} / \mathrm{L}$ bromide solution to 9.9 and $90.9 \mathrm{mg} / \mathrm{L}$. The resulting calibration was

$$
C=10[(122-E) / 58.2]
$$

where $C$ is bromide concentration in $\mathrm{mg} / \mathrm{L}$ and $E$ is measured potential in millivolts. Using this calibration, untreated ground water showed an apparent $1.81 \mathrm{mg} / \mathrm{L}$ bromide concentration. This concentration of the halide is unlikely in fresh water and is most likely the result of an interference; e.g., the result of not using an ionic strength adjuster or departure from the calibration curve as the method's detection limit was approached (detection 1 imit is nominally $0.4 \mathrm{mg} / \mathrm{L}$ ). For the purpose of analyzing the field monitoring data, $1.81 \mathrm{mg} / \mathrm{L}$ was subtracted from each measurement made.

\section{Pumpback of the Tracer}

On May 10, a pump was installed in the test well. The pump was connected to a ball valve and 2-in. PVC pipe with a pitot-type flow meter. At

(a) Hach is a registered trademark of Hach Corporation, Loveland, Colorado. 
$1118 \mathrm{~h}$, momentary testing of the pump showed that it was capable of pumping more than $120 \mathrm{gpm}$. Approximately $100 \mathrm{gal}$ were discharged during this equipment test.

On May 11, (2-1/2 days after injection) $0816 \mathrm{~h}$, the pumpback stage of the test began. Flow rate was adjusted to $60 \mathrm{gpm}$. By $1230 \mathrm{~h}$, the tracer slug was almost entirely recovered. At $1234 \mathrm{~h}$, the pumping rate was increased to $120 \mathrm{gpm}$, and sampling was continued at 20 -min intervals until $1500 \mathrm{~h}$. (This latter sampling yielded data regarding aquifer dispersivity and lithium retardation relative to bromide and was not required for velocity estimation.) All samples were collected unpreserved in $125-\mathrm{mL}$ polyethylene bottles for laboratory analysis. Figure 6 shows the results of laboratory analysis.

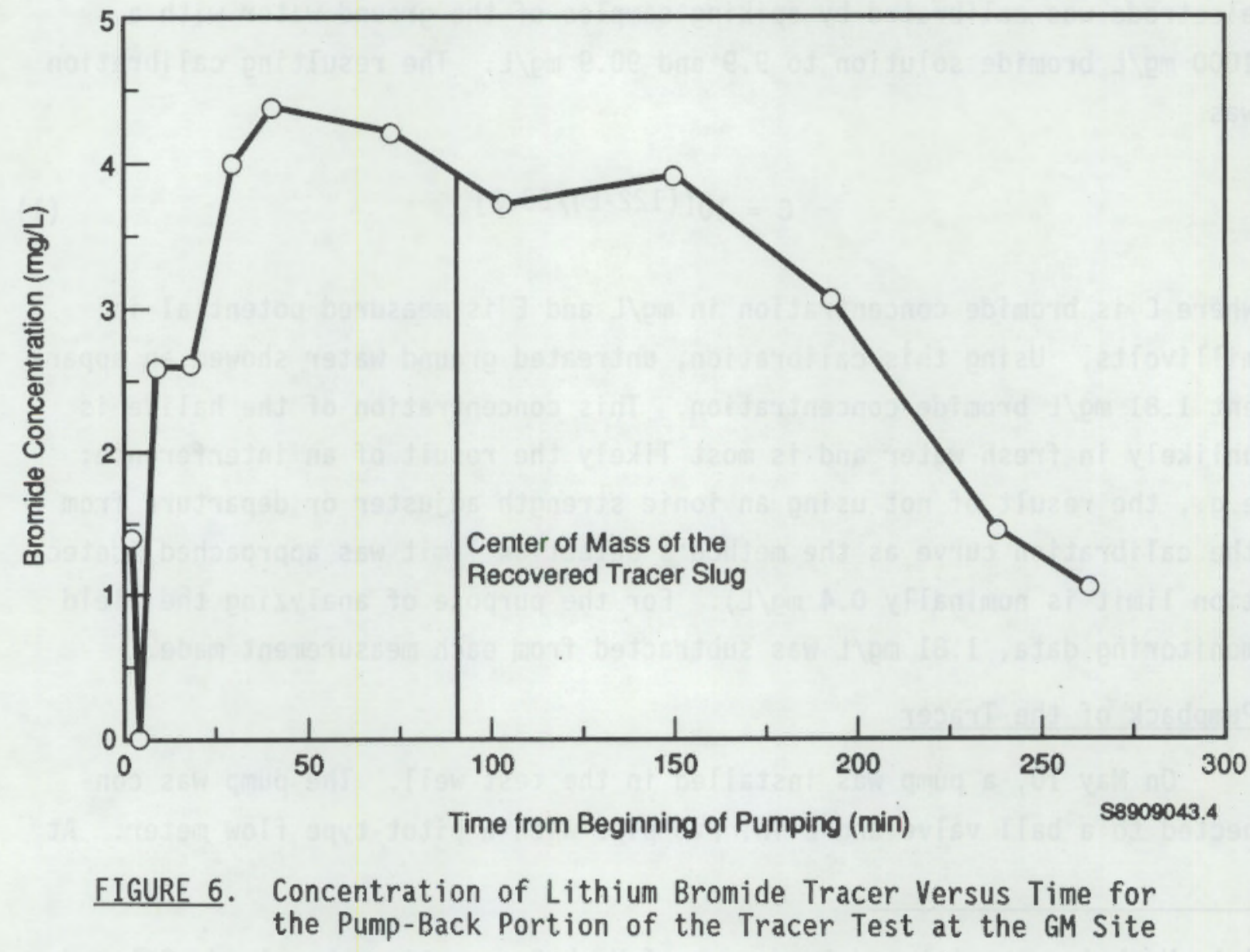




\section{Analysis of Data}

Field data show that the center of mass of the tracer slug was recovered at $0956 \mathrm{~h}$, or 100 minutes into the pumping campaign. The laboratory results indicate that the center of mass of the tracer slug was recovered 91 min into the pumping campaign. These latter results were used for data analyses to determine ground-water velocity.

\section{GROUND-WATER VELOCITY}

The average ground-water velocity in the immediate vicinity of well 4 was calculated by analysis of the aquifer test results coupled with the hydraulic gradient and by analysis of the tracer test. Effective porosity was varjed in both analyses to arrive at the velocity determinations. The calculated velocity based on hydraulic methods is proportional to the inverse of the effective porosity, while velocity calculated from the tracer test data is proportional to the square root of the effective porosity.

\section{Darcy's Law}

The results of velocity calculations from the aquifer test are based on Darcy's Law as follows:

$$
V=(K \cdot I) / n
$$

where $\quad V=$ average linear ground-water velocity

$K=$ hydraulic conductivity

$I=$ hydraulic gradient

$n=$ effective porosity.

Letting $K=40 \mathrm{ft} /$ day and $I=0.005$, velocities for a range of effective porosity $(n)$ can be calculated. These values are plotted in Figure 7.

\section{Tracer Test}

The following formula offered by Leap and Kaplan (1988) was used to calculate advective ground-water velocity from the results of the tracer test: 


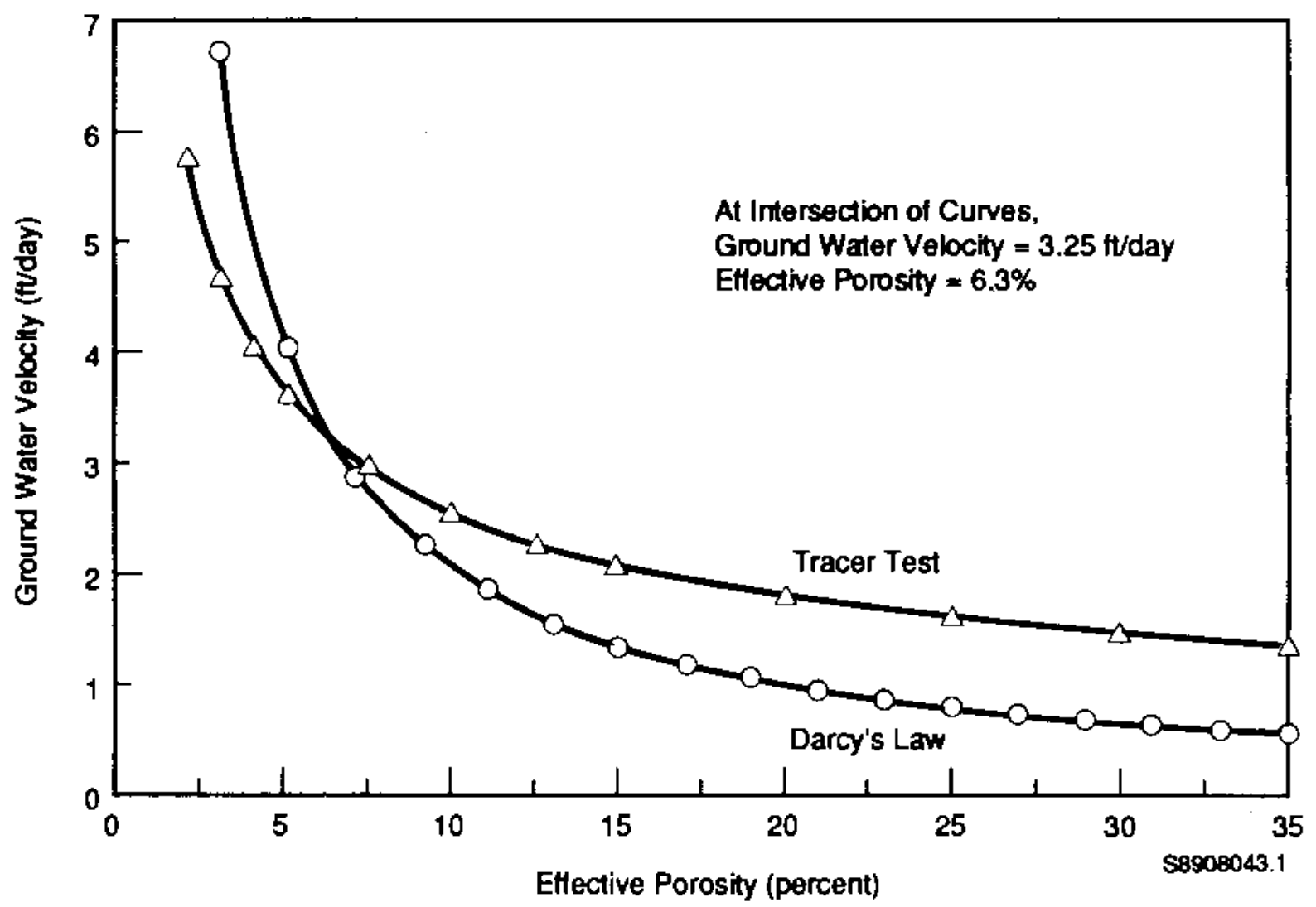

EIGURE 7. Plot of Velocity Versus Effective Porosity by Both the Tracer Test Method and Darcy's Law

$$
V=[1440 \cdot \sqrt{Q t /(n \cdot b \cdot \pi)}] / T
$$

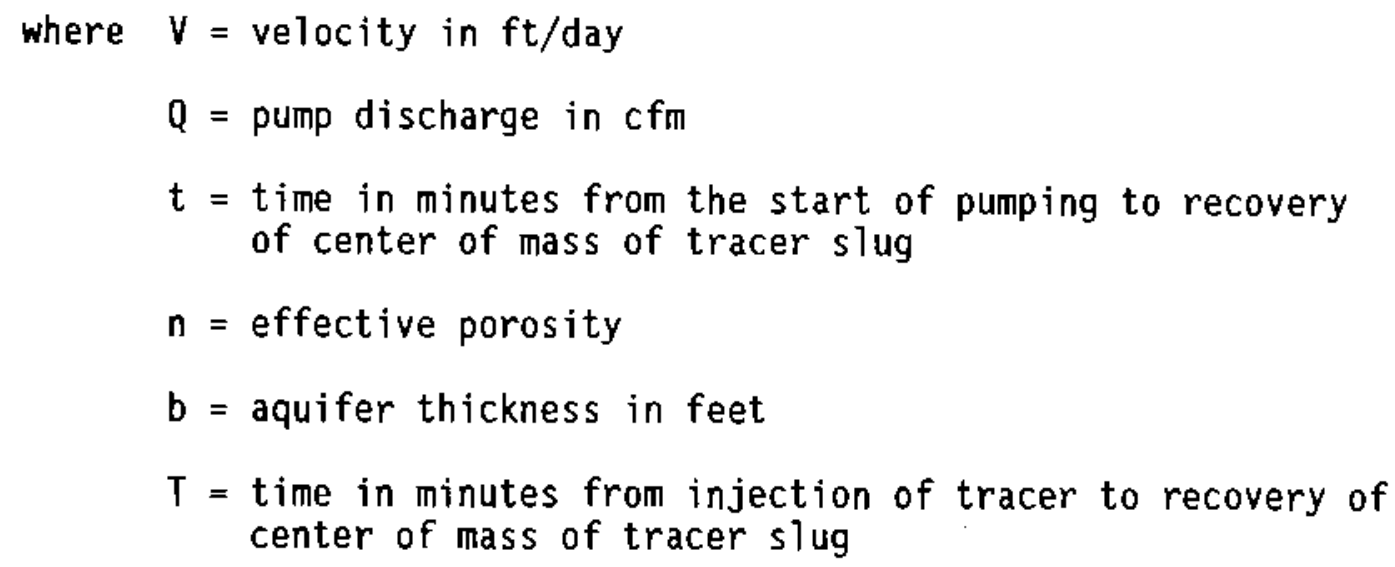


Letting $T=3848 \mathrm{~min}, b=50 \mathrm{ft}$, and $Q=60 \mathrm{gpm}$, velocities for a range of effective porosity $(n)$ can be calculated. These values are plotted on Figure 7 .

\section{Simultaneous Analysis}

The values for $V$ and $n$ are taken from the point where the curves resulting from the above equations intersect. That is, the point of intersection of the curves represents the solution of two simultaneous equations in two unknowns. The intersection of these lines results in a ground-water velocity of approximately $3.25 \mathrm{ft} /$ day, and an effective porosity of approximately $6.3 \%$. 


\section{CONCLUSIONS}

Results obtained from the aquifer test and tracer test at the GM site provided quantitative values of aquifer properties. The transmissivity is approximately $2000 \mathrm{ft}^{2} /$ day in the vicinity of wells 1 and 2 . The average hydraulic conductivity is assumed to be approximately $40 \mathrm{ft} /$ day in the same vicinity. The results of a tracer drift and pumpback test and the aquifer test were used conjunctively to determine ground-water flow velocity, which is approximately $3.25 \mathrm{ft} /$ day.

Limitations of the analyses result from the complex hydrogeologic setting, which is made up of an unconfined aquifer overlying a confining bed, which in turn overlies a confined or semiconfined aquifer. In addition, interferences from off-site pumping affected the analyses of data from the wells surrounding the GM site building.

Uncertainty still exists in quantification of the magnitude and direction of the hydraulic gradient because wells are completed in different hydrostratigraphic units and off-site pumping appears to affect ground-water flow. The calculation of ground-water velocity for the entire flow field of interest is also difficult because of these factors. 


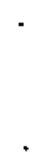




\section{REFERENCES}

Boulton, N. S. 1963. "Analysis of Data from Non-Equilibrium Pumping Tests Allowing for Delayed Yield from Storage." Inst. Civil Engineers Proc. $26: 469-482$.

Cooper, H. H., Jr. 1963. "Type Curves for Nonsteady Radia] Flow in an Infinite Leaky Artesian Aquifer." In Shortcuts and Special Problems in Aquifer Tests, ed. Ray Bental, pp. C48-C55. Water-Supply Paper 1545-C, U.S. Geological Survey, Washington, D.C.

Cooper, H. H., Jr., and C. E. Jacob. 1946. "A Generalized Graphical Method for Evaluating Formation Constants and Summarizing Well-Field History." Am. Geophys. Union Trans. 27(4):526-534.

Leap, 0. I., and P. G. Kaplan. 1988. "A Single-Well Tracing Method for Estimating Regional Advective Velocity in a Confined Aquifer: Theory and Preliminary Laboratory Verification." Water Resources Research 24(7):993-998.

Lohman, S. W. 1972. Ground-Water Hydraulics. Professional Paper 708, U.S. Geological Survey, Washingtn, D.C. 


\section{APPENDIX A}

DRILLERS' LOGS FOR WELLS DRILLED IN THE VICINITY OF THE GENERAL MOTORS HARRISON DIVISION PLANT 
DRILLERS' LOGS FOR WELLS DRILLED IN THE VICINITY OF IHE GENERAL MOTORS HARRISON DIVISION PLANT

\author{
WELL DRILLERS' RECORDS \\ General Construction Information: \\ Completion Dates: January 25 and 26, 1984 \\ Screen Length: $80 \mathrm{ft}$ \\ Screen Interval: $24-104 \mathrm{ft}$ \\ Depth to Water: $19.5 \mathrm{ft}$
}

We11 4 - Pumped We11

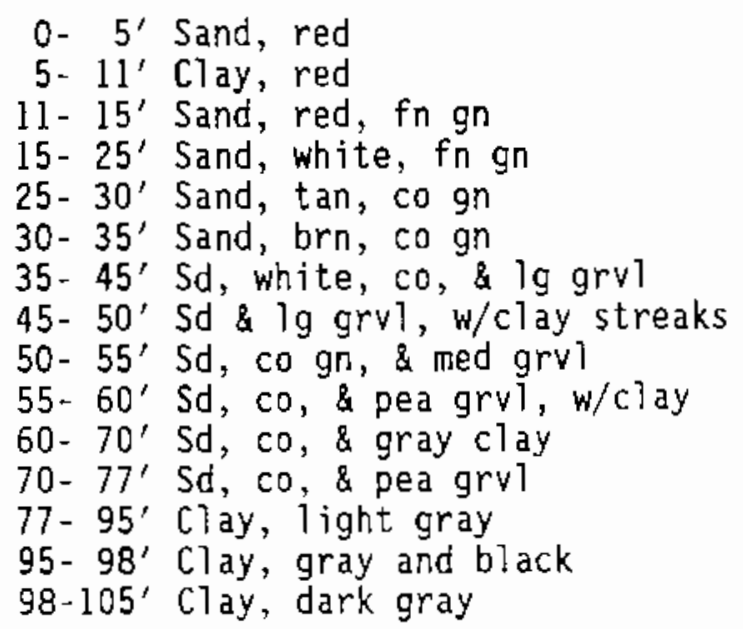

Well 1 - $40 \mathrm{ft}$ from Well 4

$$
\begin{aligned}
& \text { 0- 9' Clay } \\
& 9-15^{\prime} \text { Sand } \\
& 15-30^{\prime} \text { Sand } \\
& 30-38^{\prime} \text { Sand } \\
& 38-45^{\prime} \text { Sand \& some sm grvl } \\
& 45-58^{\prime} \text { Sand } \\
& 58-59^{\prime} \text { Clay } \\
& 59-60^{\prime} \text { Sand } \\
& 60-75^{\prime} \text { Sand w/Clay streaks } \\
& 75-79^{\prime} \text { Sand } \\
& 79-86^{\prime} \text { Clay, blue } \\
& 86-88^{\prime} \text { Sand, w/fossil \& grvl } \\
& 88-90^{\prime} \text { Clay, soft } \\
& 90-97^{\prime} \text { Clay, hard } \\
& 97-98^{\prime} \text { Sand w/some coal bits } \\
& 98-105^{\prime} \text { Clay (Pottsville) }
\end{aligned}
$$

Wel1 $3-160 \mathrm{ft}$ from Wel] 4

$$
\begin{aligned}
& 0-12^{\prime} \text { C Tay } \\
& \text { 12- 15' Sand } \\
& \text { 15- 30' Sand } \\
& \text { 30- } 45^{\prime} \text { Sand \& } 19 \mathrm{grvl} \\
& \text { 45- 56' Sand } \\
& \text { 56- 60' Clay, blue } \\
& 60-63^{\prime} \text { Clay } \\
& 63-75^{\prime} \text { Sand \& med grvi } \\
& \text { 75- 80' Sand } \\
& \text { 80- 85' Clay, soft } \\
& \text { 85- 90' Clay, hard } \\
& \text { 90-100' Clay, hard } \\
& \text { 100-105' Clay, very hard }
\end{aligned}
$$




\section{WELL DRILLERS' LOG INFORMATION}

Drilling Company: Mid-South Drilling Company, Carrollton, AL 35447

All wells are 2-in.-diameter PVC; screens are 10-ft long, 0.02-in. slot size

Well 5

Completion Date: $\quad 9 / 20 / 88$

Static Water Level: $23 \mathrm{ft}$

Total Drilled Depth: $78 \mathrm{ft}$

Screened Interval: $43-53 \mathrm{ft}$

$0-7^{\prime}$ Sandy clay

$7-13^{\prime}$ Clay

$13-50^{\prime}$ Sand

$50-54^{\prime}$ Clay

54-61' Sand \& pea gravel

$61-70^{\prime}$ Sand

70-78' Sand \& pea grave]

We11 7

Completion Date: $\quad 9 / 21 / 88$

Static Water Leve1: $21 \mathrm{ft}$ Total Drilled Depth: $51 \mathrm{ft}$

Screened interval: $41-51 \mathrm{ft}$

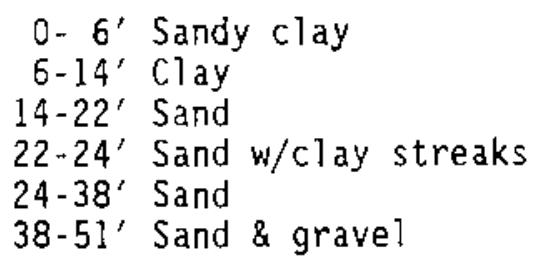

Wei) 9

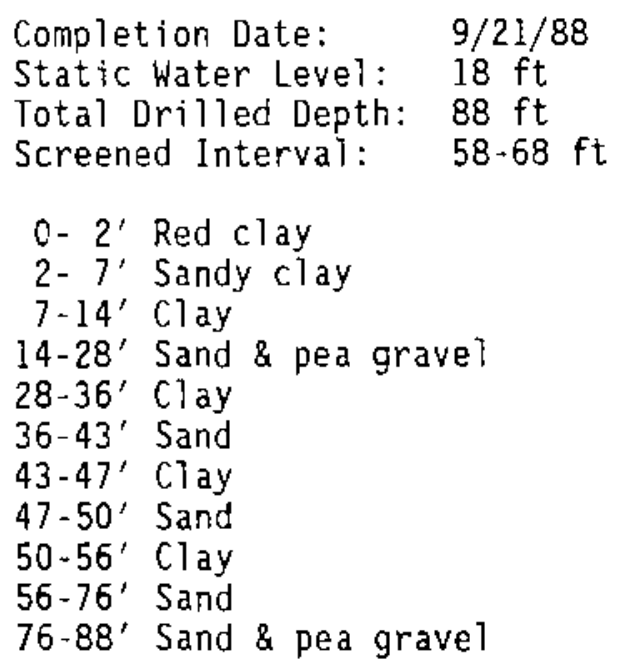

We116

Completion Date: $\quad 9 / 21 / 88$

Static Water Level: $23 \mathrm{ft}$

Total Orilled Depth: $83 \mathrm{ft}$

Screened Interval: $\quad 48-58 \mathrm{ft}$

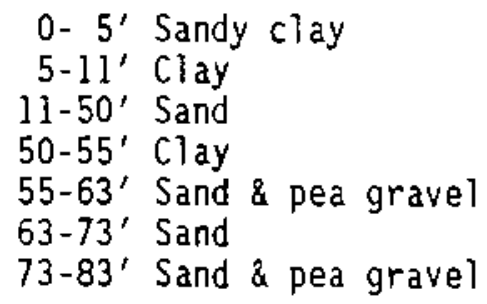

0 - 5' Sandy clay

5-11' Clay

$11-50^{\prime}$ Sand

$50-55^{\prime}$ Clay

$55-63^{\prime}$ Sand \& pea gravel

$63-73^{\prime}$ Sand

73-83' Sand \& pea gravel

Wel1 8

Completion Date: $9 / 21 / 88$

Static Water Leve 1: $15 \mathrm{ft}$

Total Drilled Depth: $82 \mathrm{ft}$

Screened Interval: $\quad 47-57 \mathrm{ft}$

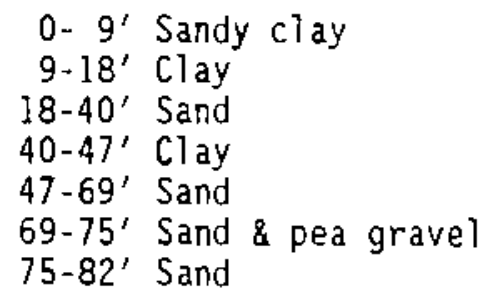


APPENDIX B

\section{PLOTS OF AQUIFER TEST DATA FOR A TEST CONDUCTED AT}

THE GENERAL MOTORS HARRISON DIVISION PLANT 


\section{APPENDIX B}

\section{PLOTS OF AQUIFER TEST DATA FOR A TEST CONDUCTED AT THE GENERAL MOTDRS HARRISON DIVISION PLANT}

This appendix contains plots of drawdown and recovery data, and results of the data analyses for the aquifer test conducted at the General Motors Harrison Division Plant, May 4, 1989, through May 6, 1989. A copy of delayed-yield type curves from Lohman (1972), which were used to analyze the data, is also included.

The following identifies the data plots and analyses included:

- Observation well 1 drawdown and recovery

- Observation well 2 drawdown and recovery

- Observation well 3 drawdown and recovery

- Pump well 4 drawdown and recovery

- Observation we11 5 drawdown

- Dbservation well 7 drawdown

- Delayed-yield type curves.

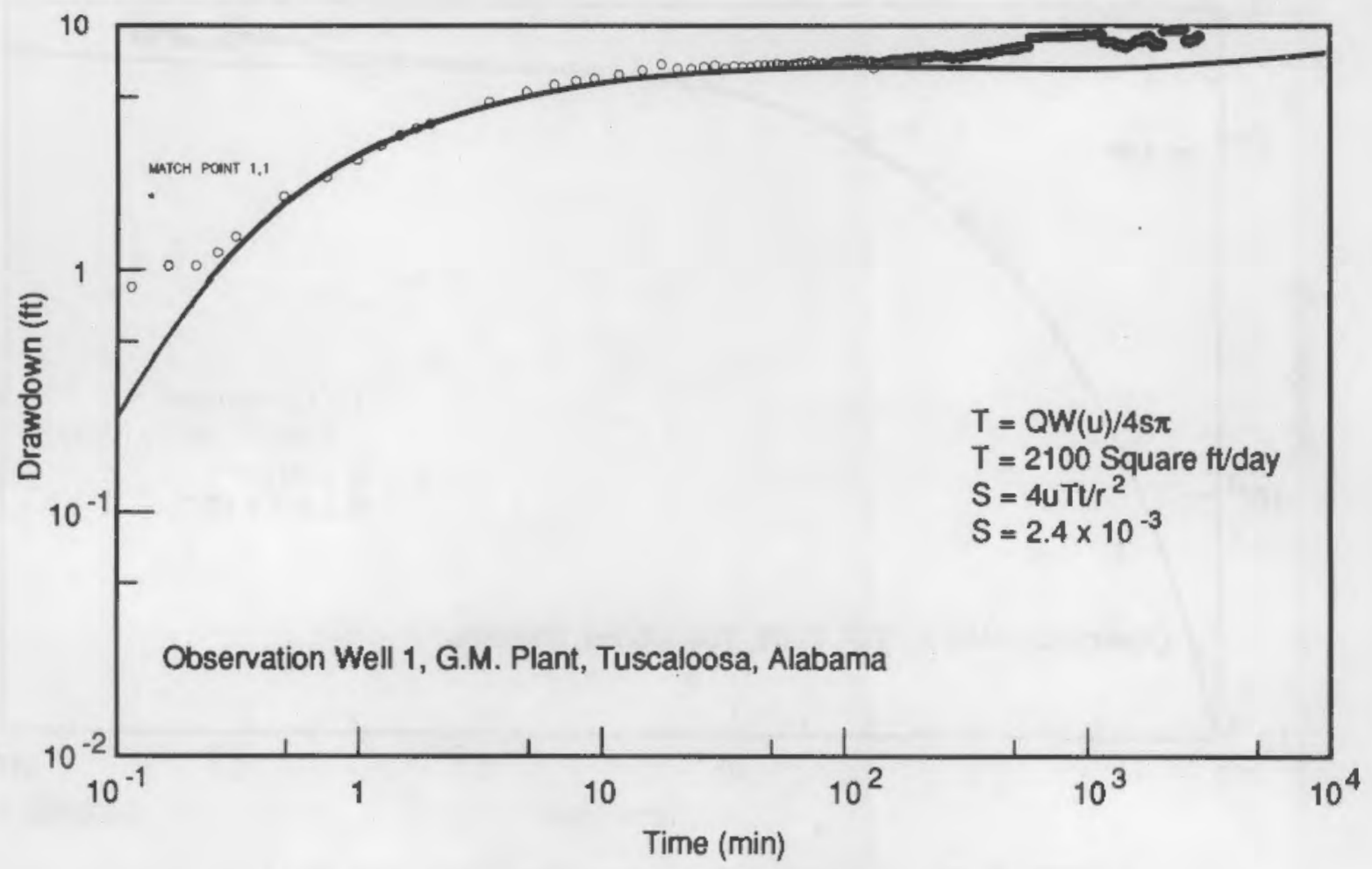

FIGURE B.1. Drawdown Data and Analysis for Well 1 


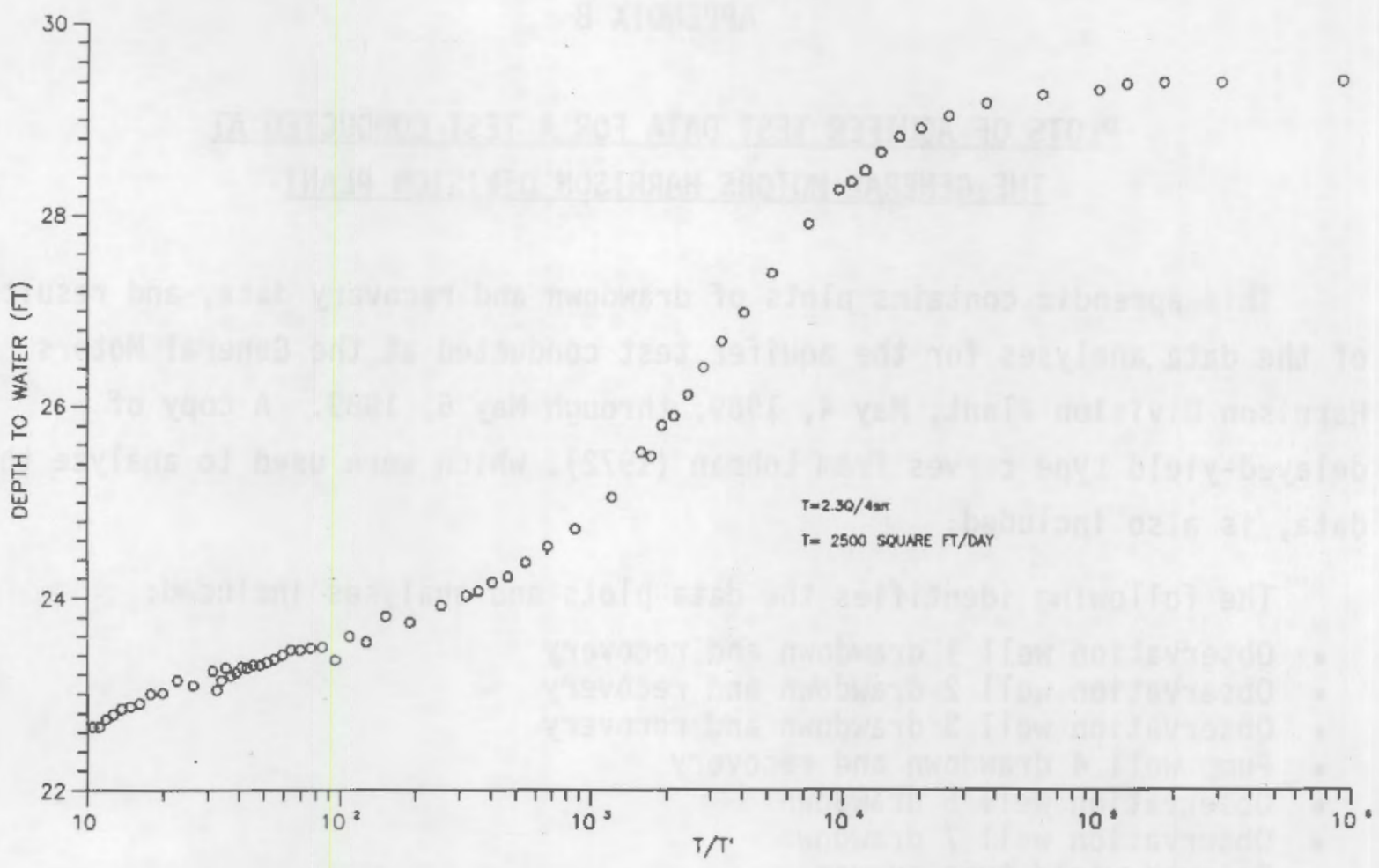

FIGURE B.2. Recovery Data and Analys is for Well 1

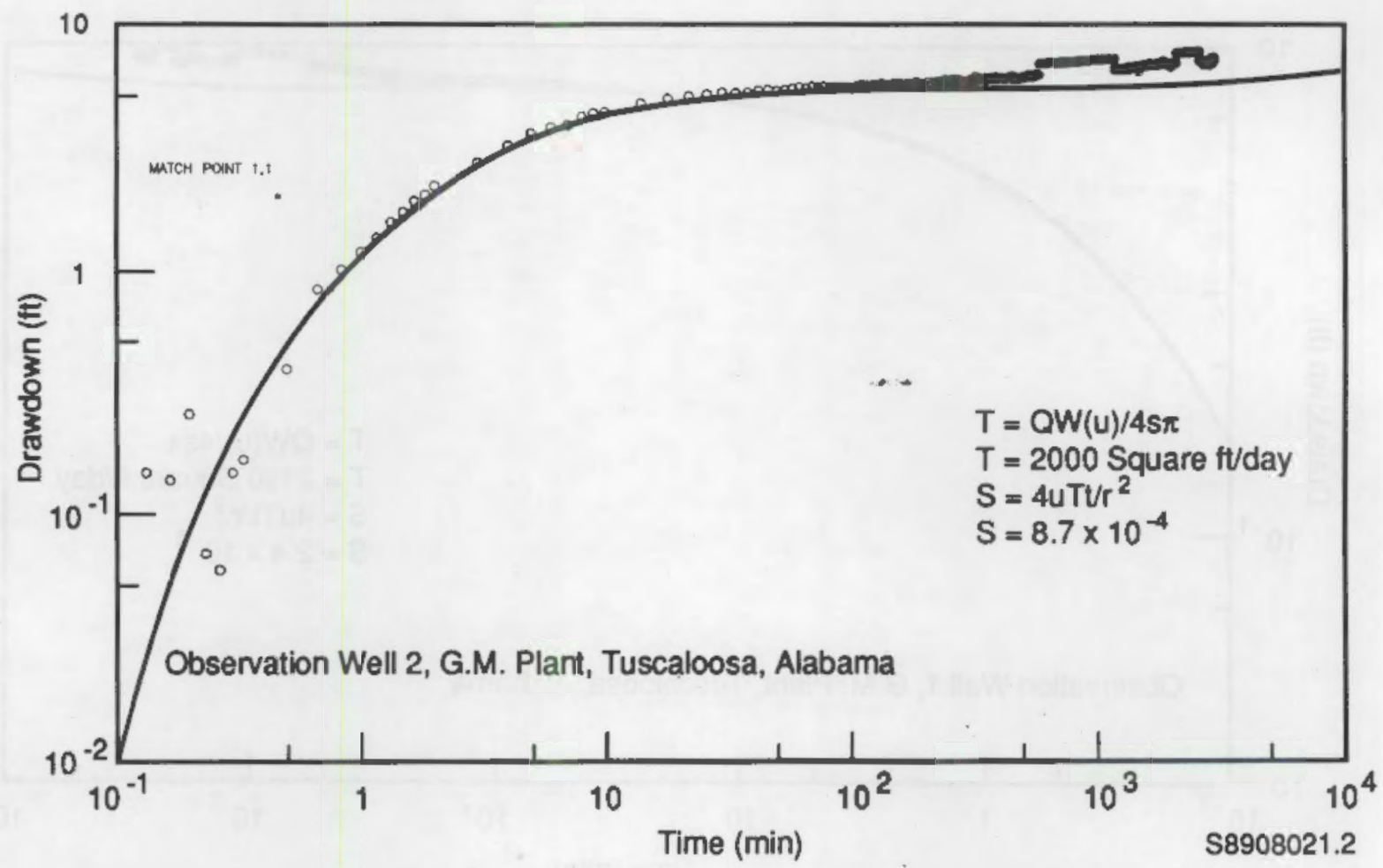

FIGURE B.3. Drawdown Data and Analysis for Well 2 


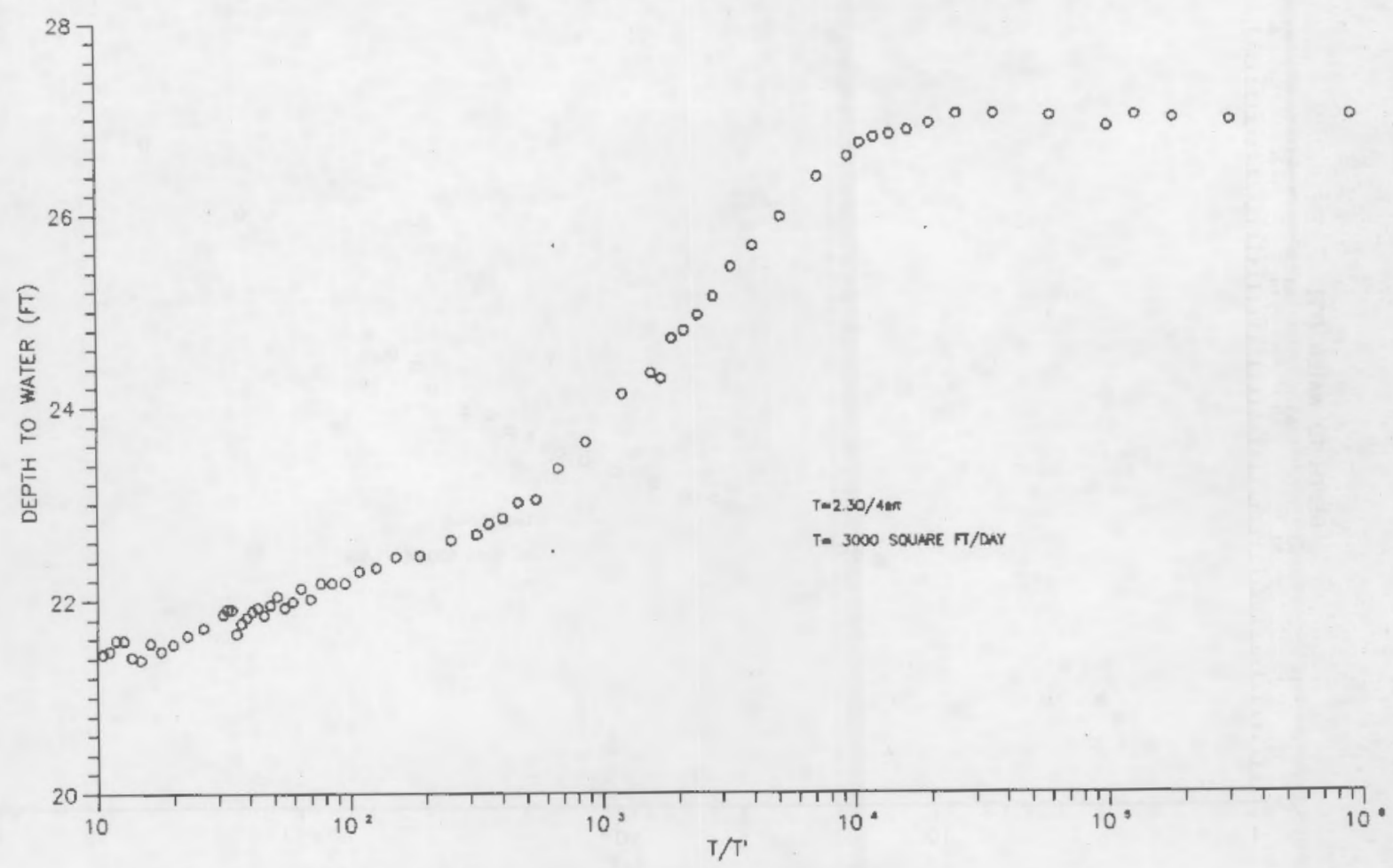

FIGURE B.4. Recovery Data and Analysis for Well 2

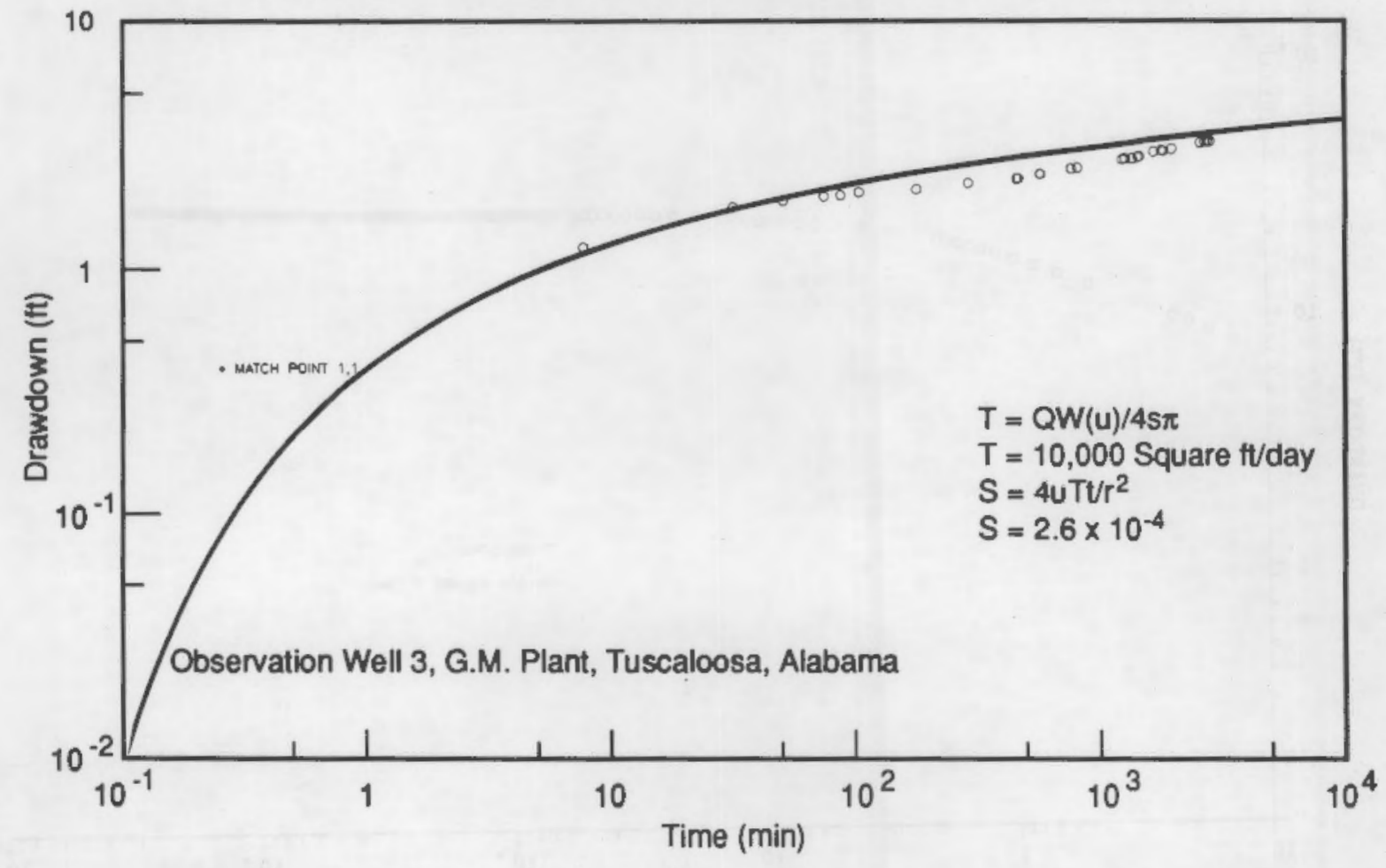

FIGURE B.5. Drawdown Data and Analys is for Well 3

\section{B. 3}




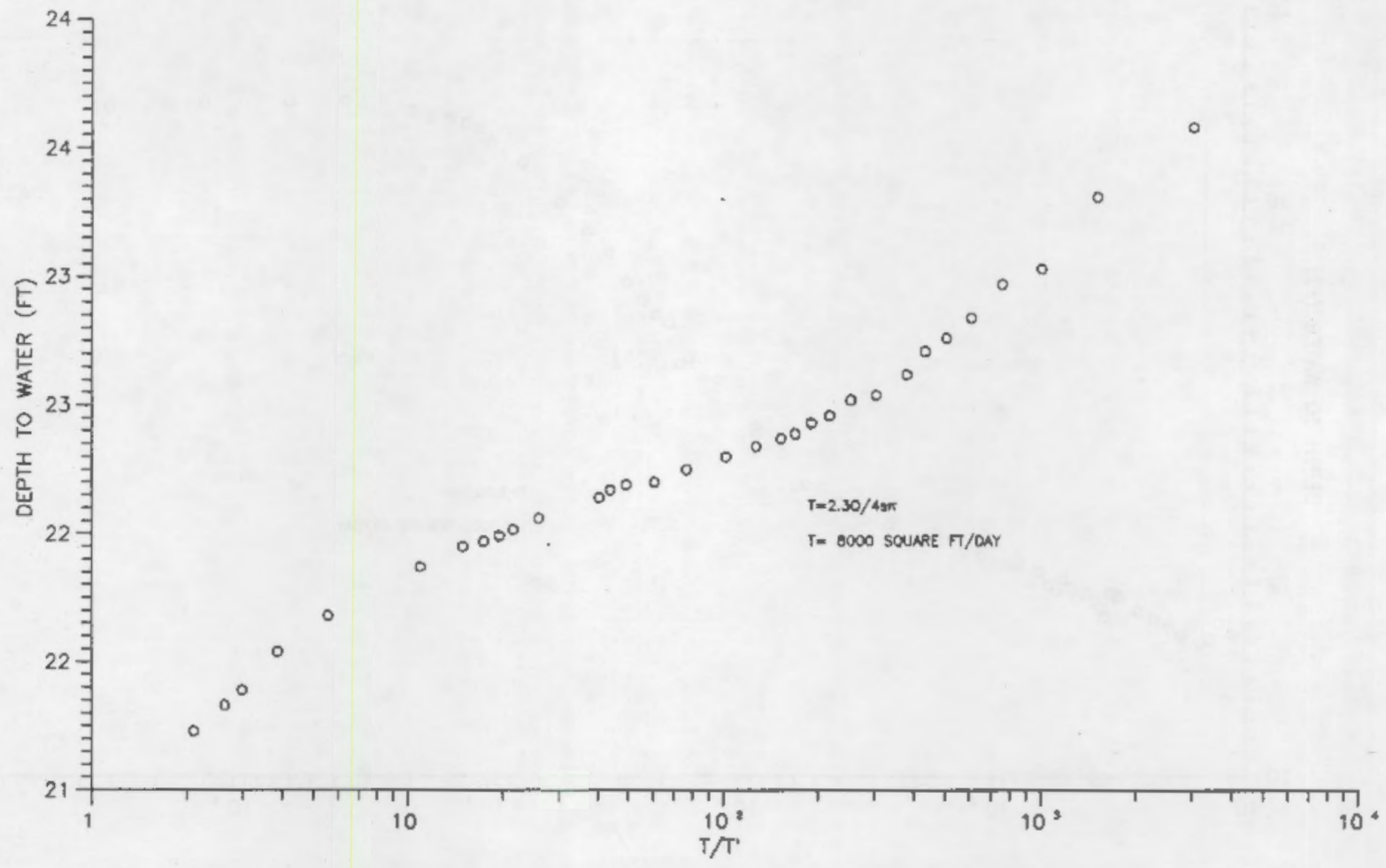

FIGURE B.6. Recovery Data and Analysis for Well 3

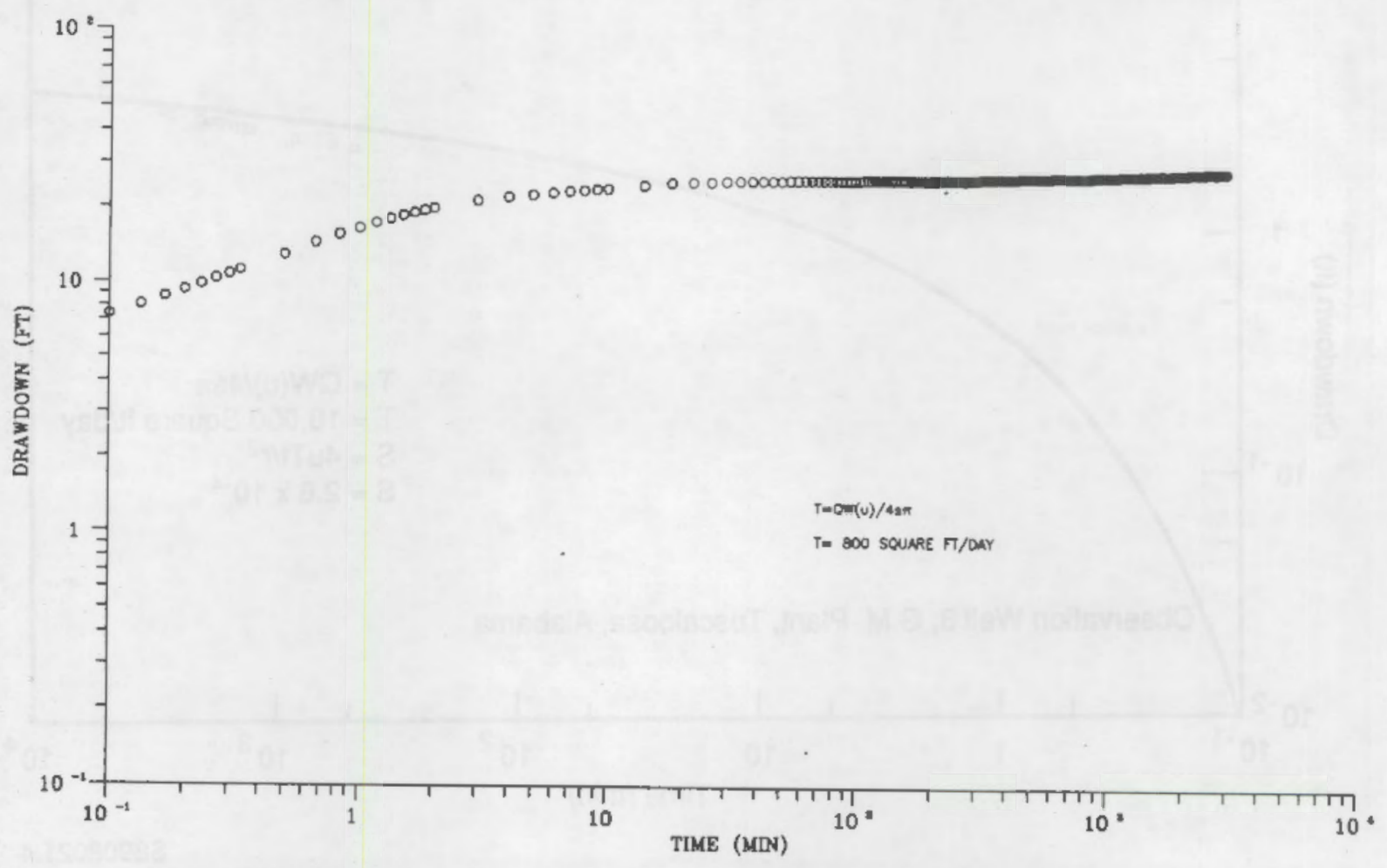

FIGURE B.7. Drawdown Data and Analys is for Well 4 


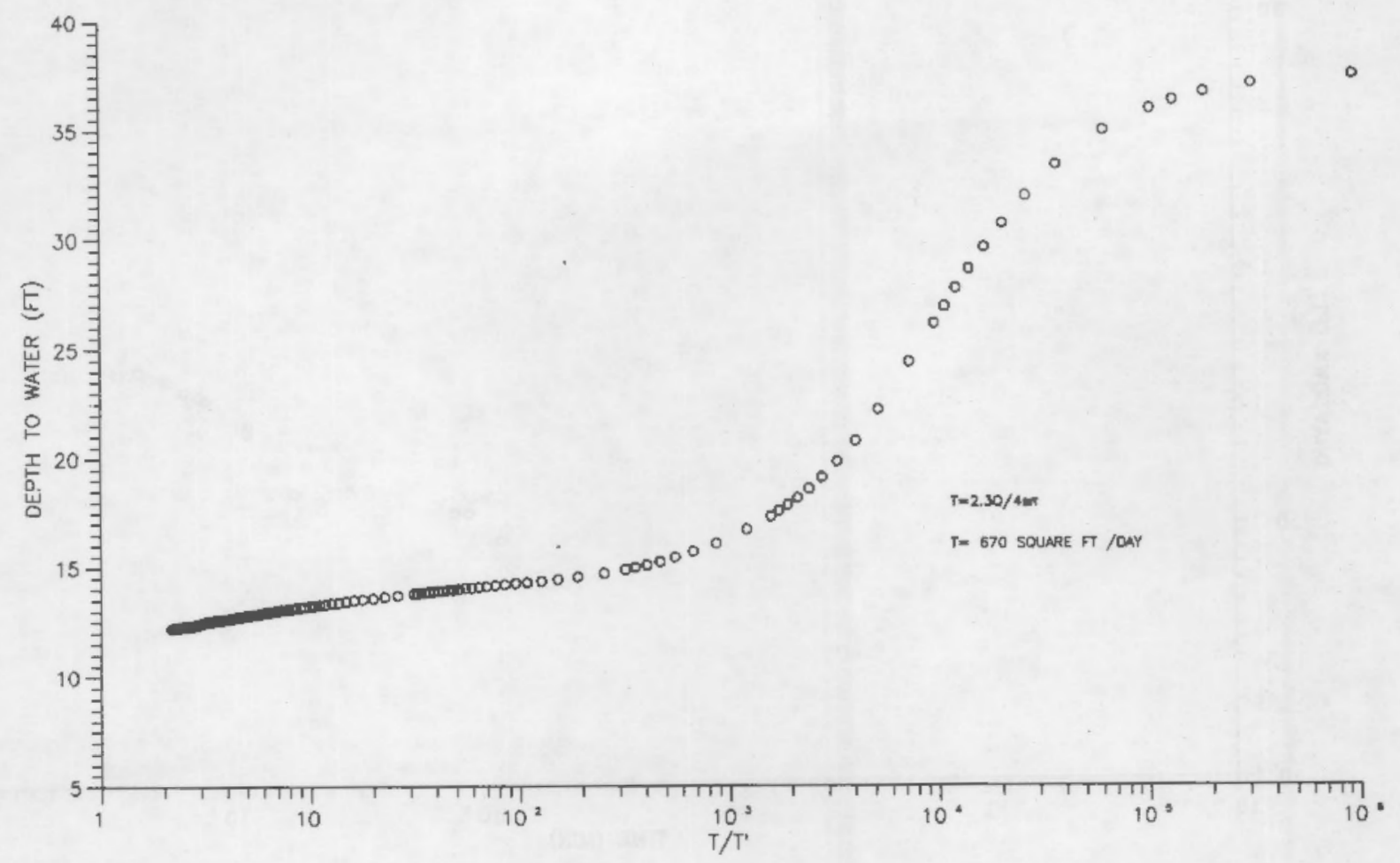

FIGURE B.8. Recovery Data and Analysis for Well 4

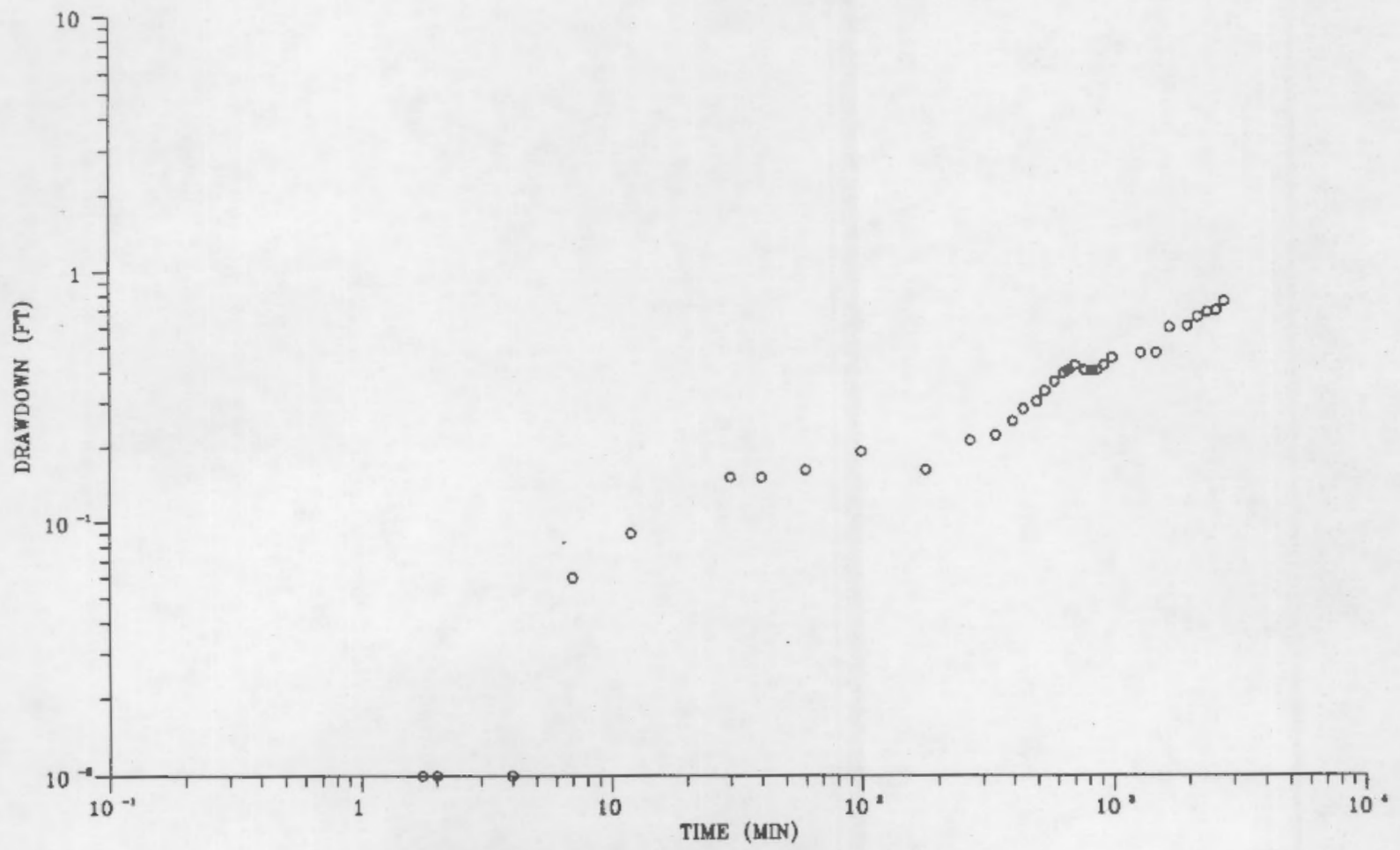

FIGURE B.9. Drawdown Data for Well 5

\section{B. 5}




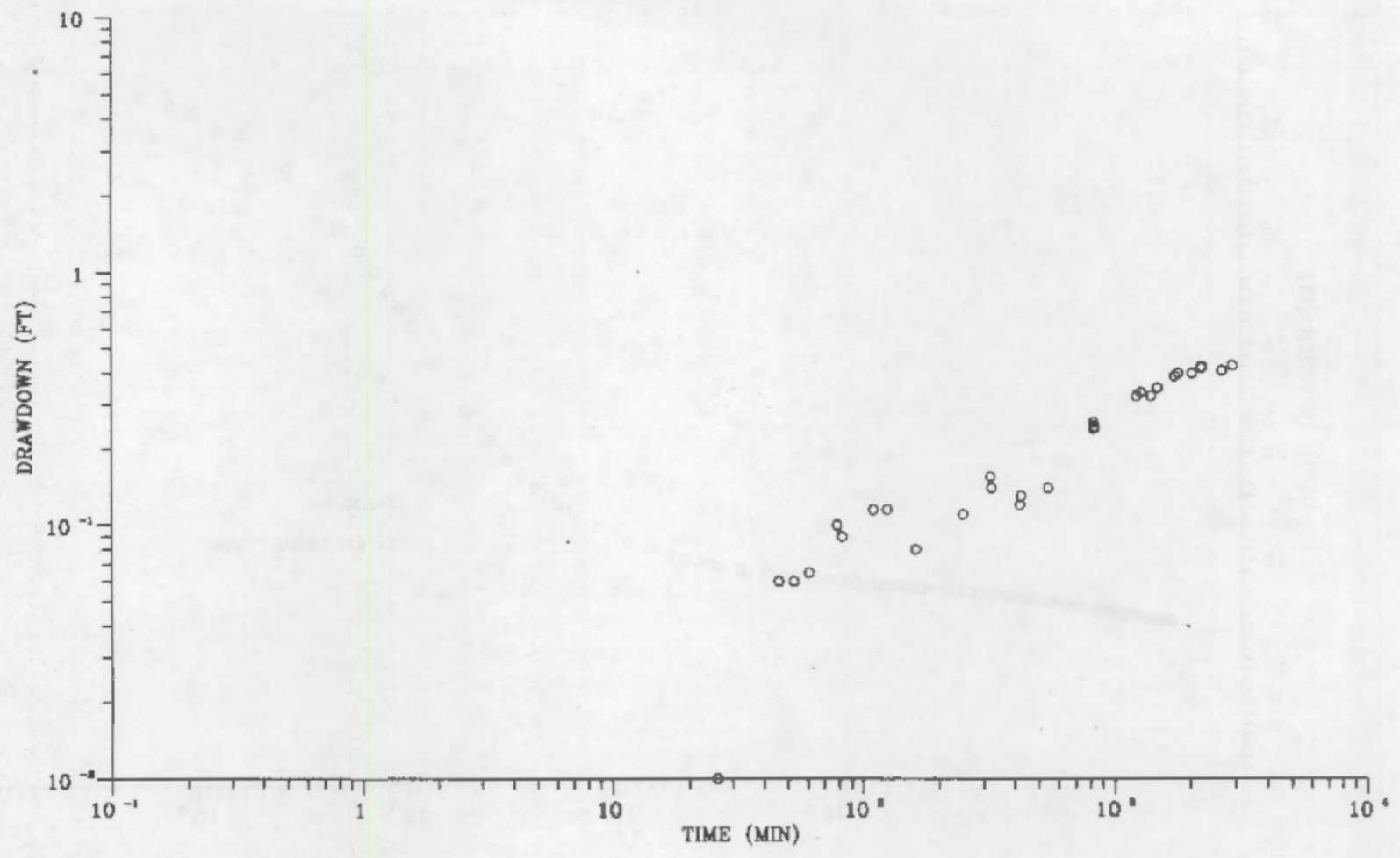

FIGURE B.10. Drawdown Data for Well 7 
UNITED STATES DEPARTMENT OF THE INTERIOR

EOLOGICAL SURVEY PLATE 8

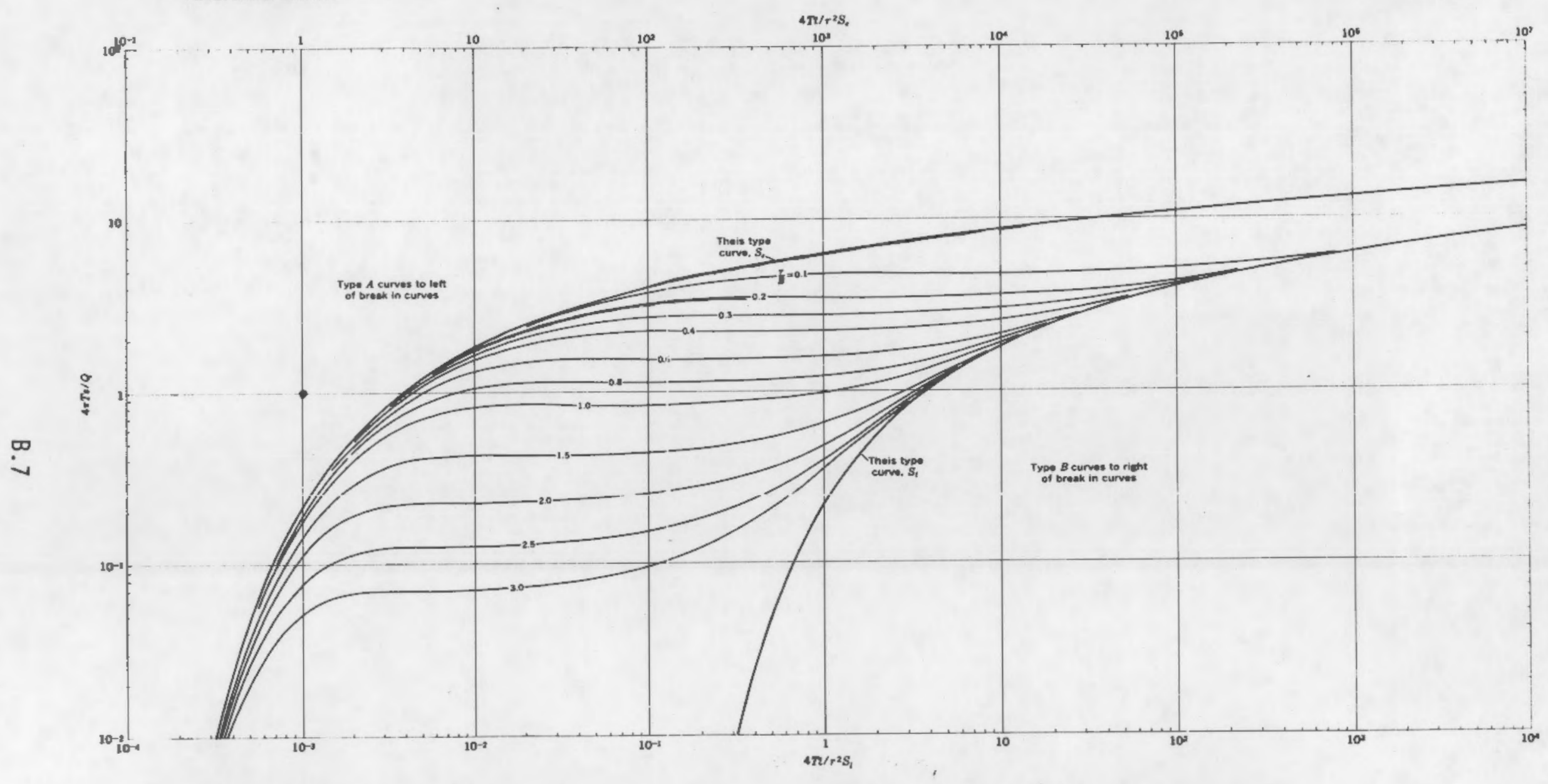

FIGURE B.11 Delayed-Yield Type Curve 


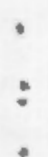




\section{REFERENCE}

Lohman, S. W. 1972. Ground-Water Hydraulics. Professional Paper 708, U.S. Geological Survey, Washington, D.C. 


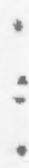




\section{DISTRIBUTION}

No. of

Copies

OFFSITE

U.S. Department of Energy

Attn: K. Klein

Office of Energy Storage \& Dist.

Forrestal Bldg, CE-32 5E-036

Washington, DC 20585

U.S. Department of Energy

Attn: E. Reimers

Office of Energy Storage \& Dist.

Forrestal B1dg, CE-32 5E-036

Washington, DC 20585

12 DOE/Office of Scientific and

Technical Information

University of Alabama

Attn: C. E. Brett

School of Mines and Energy Development

Box 6282

University, AL 35486

University of Alabama

Attn: Y. K. Song

Box 870276

University, AL 35486
No. of

Copies

ONSITE

DOE Richland Operations Office

D. R. Segna, A5-90

35 Pacific Northwest Laboratory

M. P. Bergeron, K6-77

R. W. Bryce, $\mathrm{K} 6-96$

W. E. Cronin, K6-77

J. W. Falco, K6-78

J. M. Hales, K6-04

S. H. Hall, K6-96

P. C. Hays, K6-86

L. D. Kannberg, K5-21 (10)

S. P. Luttrel1, K6-96 (3)

W. T. Penne11, K6-08

J. R. Raymond, $\mathrm{K} 6-77$

R. L. Skaggs, K6-77

R. M. Smith, K6-96

J. L. Smoot, K6-77

L. W. Vail, K6-77

R. W. Wallace, K6-77

J. R. Weber, K3-53

R. E. Wildung, P7-50

Publishing Coordination

Technical Report Files (5) 
